\title{
Seasonal Variations in Groundwater of the Phreatic Aquiferous Formations in Douala City-Cameroon: Hydrogeochemistry and Water Quality
}

\author{
Richard Ayuk Akoachere1, Sonia Ebot Egbe1, Thomson Areapkoh Eyong1, \\ Sophie Ngomune Edimo ${ }^{2}$, Simon Ngomba Longonje ${ }^{3}$, Diana Besem Tambe ${ }^{4}$, \\ Nji Bihmimihney Nelly 1 \\ ${ }^{1}$ Department of Geology, University of Buea, Cameroon \\ ${ }^{2}$ Department of Environmental Mines and Geology (CEA-MEM), Felix Houphuoet-Boigny National Polytectnic Institute, \\ Còte D’Ivoire \\ ${ }^{3}$ Department of Environmental Science, University of Buea, Cameroon \\ ${ }^{4}$ Advanced School of Public Works Yaounde, Cameroon \\ Email: r.akoachere@ubuea.cm
}

How to cite this paper: Akoachere, R.A., Egbe, S.E., Eyong, T.A., Edimo, S.N., Longonje, S.N., Tambe, D.B. and Nelly, N.B. (2019) Seasonal Variations in Groundwater of the Phreatic Aquiferous Formations in Douala City-Cameroon: Hydrogeochemistry and Water Quality. Open Access Library Journal, 6: e5328.

https://doi.org/10.4236/oalib.*****

Received: March 12, 2019

Accepted: April 23, 2019

Published: April 26, 2019

Copyright () 2019 by author(s) and Open Access Library Inc.

This work is licensed under the Creative Commons Attribution International License (CC BY 4.0).

http://creativecommons.org/licenses/by/4.0/

\begin{abstract}
This study carried out in Douala City, was to determine the seasonal variations of groundwater, the influence of the rock formations on the groundwater solute chemistry and groundwater domestic-agro-industrial quality using hydrogeochemical tools and physicochemical parameters, Ionic ratios, Gibbs diagrams, Piper diagrams, Durov diagrams and water quality indices. From physicochemical parameters, in the rainy season, $\mathrm{pH}$ ranged from, 4.6 - 7.1; EC, $0.023-1.63 \mathrm{mS} / \mathrm{cm}$, Temperature, $26.3^{\circ} \mathrm{C}-29^{\circ} \mathrm{C}$ and TDS, $0.015-1.09$ $\mathrm{mg} / \mathrm{L}$, and in the dry season $\mathrm{pH}$ ranged from $5-7.2, \mathrm{EC}, 0.01-1.61 \mathrm{mS} / \mathrm{cm}$, Temperature, $24.4^{\circ} \mathrm{C}-29.5^{\circ} \mathrm{C}$ and TDS, $0.01-1.08 \mathrm{mg} / \mathrm{L}$. Forty groundwater samples, 20 per season, wet and dry were analysed. The major ions fell below WHO acceptable limits for both seasons. The sequences of abundance of major ions were, $\mathrm{Ca}^{2+}>\mathrm{K}^{+}>\mathrm{Mg}^{2+}>\mathrm{NH}_{4}^{+}>\mathrm{Na}^{+}, \mathrm{HCO}_{3}^{-}>\mathrm{Cl}^{-}>\mathrm{SO}_{4}^{2-}>$ $\mathrm{NO}_{3}^{-}>\mathrm{HPO}_{4}^{2-}$ in wet season and $\mathrm{Ca}^{2+}>\mathrm{Mg}^{2+}>\mathrm{K}^{+}>\mathrm{Na}^{+}>\mathrm{NH}_{4}^{+}$, $\mathrm{HCO}_{3}^{-}>\mathrm{Cl}^{-}>\mathrm{SO}_{4}^{2-}>\mathrm{HPO}_{4}^{2-}>\mathrm{NO}_{3}^{-}$in dry season. Ion-exchange, simple dissolution and uncommon dissolution processes determined groundwater character. Groundwater ionic content was as a result of ion exchange from rock-weathering. Water types are; $\mathrm{MgCl}$ and $\mathrm{MgHCO}_{3}$ in both seasons. Hydrogeochemical facies are; $\mathrm{Ca}-\mathrm{Mg}-\mathrm{Cl}-\mathrm{SO}_{4}$, characteristic of groundwater some distance along its flow path and $\mathrm{Ca}-\mathrm{Mg}-\mathrm{HCO}_{3}$, characte-
\end{abstract}


ristic of freshly recharged groundwater from precipitation. The groundwater indices of Sodium Percent (\% Na), Residual Sodium Carbonate (RSC), Kelley's ratio (KR), Sodium Adsorption Ratio (SAR), Electrical Conductivity (EC), Total Dissolved Solid (TDS), USSL and Wilcox index were determined, evaluated and found to be suitable for agro-industrial uses in all seasons. Permeability Index (PI), Water quality index (WQI) and Magnesium Adsorption Ratio (MAR) were not suitable in some areas and in some seasons.

\section{Subject Areas}

Geochemistry, Hydrology

\section{Keywords}

Groundwater, Hydrogeochemistry, Seasonal Variations, Water Quality, Douala-Cameroon

\section{Introduction}

Douala situated between latitude $4.00-4.15$ and longitude $9.65-9.95$, is the economic capital of Cameroon in the Littoral Region hosts more than $80 \%$ of the industries in the Country. It is divided into districts: Akwa, Bassa, Bonaberi, Bonapriso, Bonanjo, Deïdo, NewBell, Akwa North, Madagascar, Yassa, Nyalla, Logbaba, Ndogsimbi, Ndokoti, Ndogpassi, Cite Sic, Logpom as in Figure 1. The city handles most of the country's major exports, such as palm oil, cocoa, coffee, timber, metals, fruits. Rivers, spring and wells represent the major sources of water supply to the inhabitants and animal population in the tropical zones and their pollution constitute serious health risks. According to [1], Douala rests directly on unconsolidated alluvial deposits, hosts the largest urban population in the country with a population density of 350 persons per $\mathrm{km}^{2}$. Inadequate supply of pipe-borne water with only 65.000 persons connected out of 3 million inhabitants pushes the population to depend on groundwater. In Douala, groundwater is the major source of water supply for a large part of the population. The soils vary from yellow through brown to black freely drained sandy, ferralitic soils sandy at the base and sandy-clayey at the top soils [2]. Smaller tributaries like rivers Tongo, Bassa and Ngoua feed major rivers Wouri and Dibamba, which eventually empty in the Atlantic Ocean. The area is characterized by a hyper humid equatorial climate modified by the relief of Mt Cameroon with two seasons, a rainy (April to October) and a dry season (November to March) [3] [4]. Thirty years (1980-2011) of meteorological data from the national archive in Douala show that in the rainy season the average annual rainfall in the study area is $4000 \mathrm{~mm}$ /year, and the average monthly temperature is $33^{\circ} \mathrm{C}$ according to [5].

\section{Geologic Setting of the Study Area}

The Douala Basin covers some $26,500 \mathrm{~km}^{2}$. About $70 \%$ is located offshore, half 
of which is in deep water. The basin is mainly on- and off-shore Cameroon. To the west and southwest, it extends into the territorial waters of Equatorial Guinea. A number of geological features delimit the basin-The Cameroon Volcanic Line to the northwest, the Pan African Fold Belt to the east and the Kribi Fracture Zone to the south. The basin is believed to extend westward up to the Gabon-Douala Deep Sea Basin. The Douala Basin is the northernmost of a series of basins located along the South Atlantic margin of Africa. The history of this basin began in Late Jurassic time as a series of northwest-southeast trending intra-cratonic rift basins formed in response to the separation of South America from Africa.

The successive Neocomian and Barremian sequences record two major phases of non-marine sedimentation and rifting, which culminated in the formation of a regional peneplain toward the end of the period. The Late Barremian peneplain was flooded by marine deposits of Aptian age that include thick sequences of salt. This early basin history is unrecorded in the Douala Basin as well as generally do not penetrate sediments older than Aptian. Nonetheless, the thick section below the level of Aptian penetration suggests that the non-marine successions recorded in the basins to the south are also present in the Douala Basin. Salt occurs in the southern part of the basin which is Cretaceous in age and is interpreted to be Aptian by analogy with its dated equivalent in Gabon. The main rock types in Douala City include; sandstones, limestone, shale, and alluvium [6] as in Figure 2. Regional stratigraphic and tectonics can be summarized in four main phases of evolution related to pre, syn and post-rift separation of Africa from South America [7].

\section{Materials and Methods}

\subsection{Materials}

The field materials and equipment used in the study are listed in Table 1.

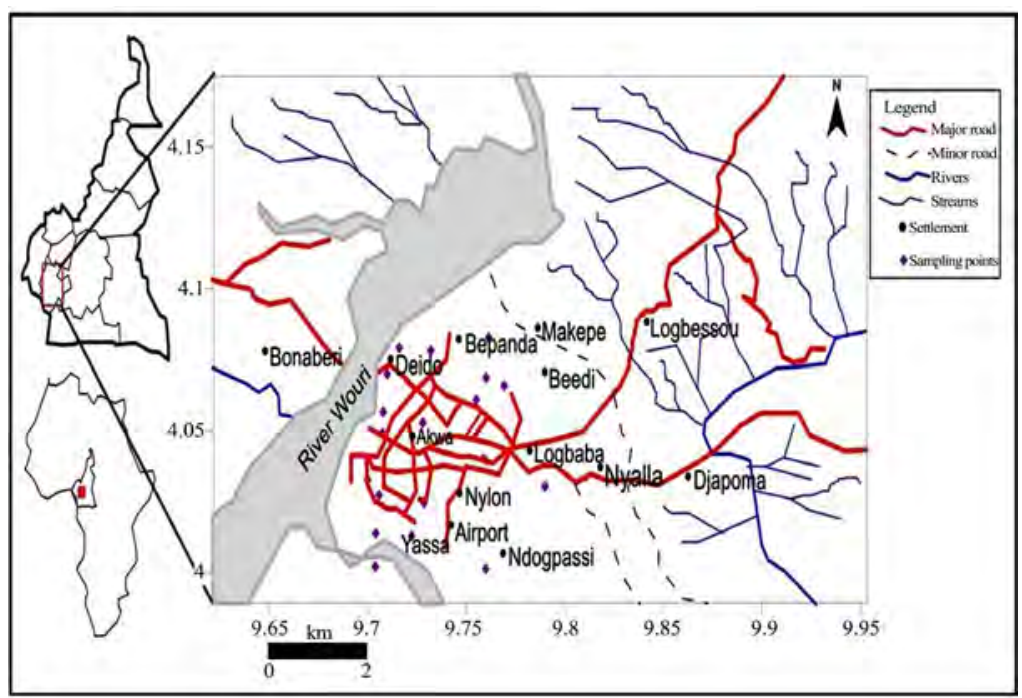

Figure 1. Location map of the study area showing field tested and sampling points. 


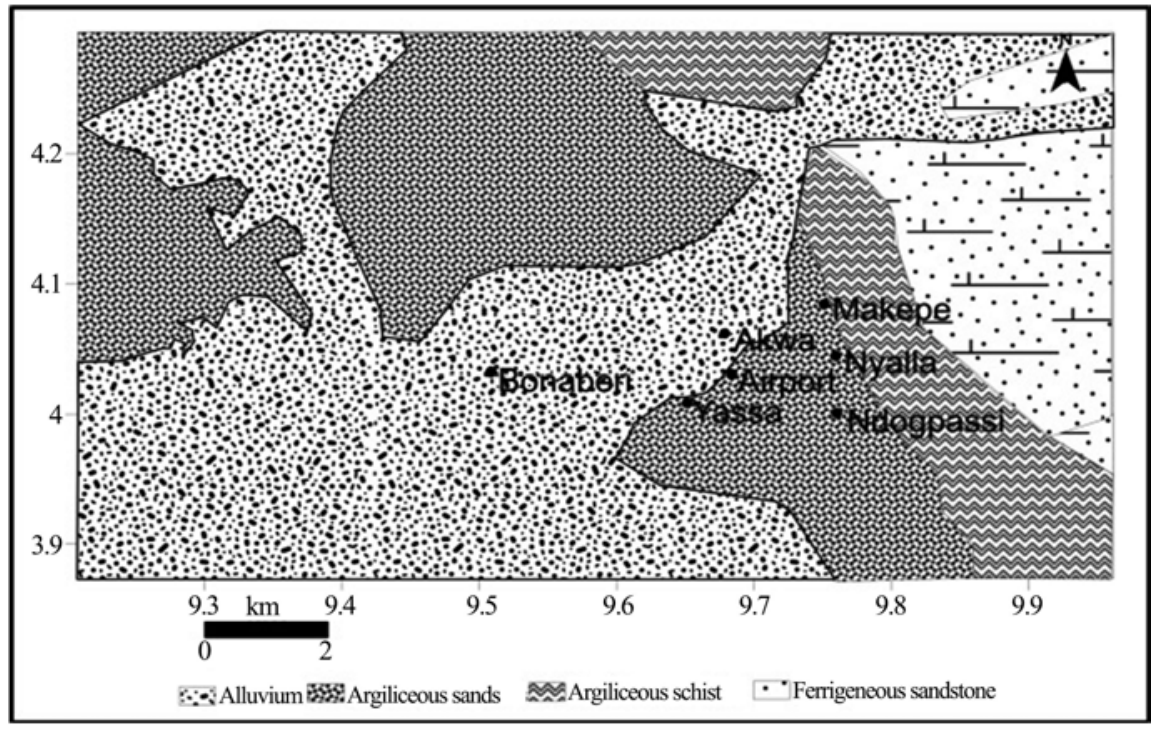

Figure 2. Geologic map of Douala and environs.

Table 1. Field equipment, specifications, and functions.

\begin{tabular}{|c|c|c|}
\hline Equipment/Softwares & Specifications & Functions \\
\hline Bike & $\begin{array}{l}\text { Commercial bikes } \\
\text { (Benskin) }\end{array}$ & $\begin{array}{c}\text { To transport } \\
\text { fieldworkers to wells }\end{array}$ \\
\hline GPS & GARMIN GPSMAP 60CSx & $\begin{array}{l}\text { To measure longitude, } \\
\text { latitude, and elevation of wells }\end{array}$ \\
\hline EC Meter & HANNA HI 98304/HI98303 & $\begin{array}{l}\text { To measure Electrical } \\
\text { Conductivity of water. }\end{array}$ \\
\hline $\mathrm{pH}$ Meter & HANNA HI 98127/HI98107 & $\begin{array}{l}\text { To measure } \\
\text { the } \mathrm{pH} \text { of water. }\end{array}$ \\
\hline Water level indicator & Solinst Model 102M & $\begin{array}{l}\text { To indicate static water } \\
\text { levels of water in wells }\end{array}$ \\
\hline Measuring Tape & Weighted measuring tape & $\begin{array}{l}\text { Measurement of well } \\
\text { diameter and depth. }\end{array}$ \\
\hline Digital Thermometer & Extech $39240\left(-50^{\circ} \mathrm{C}\right.$ to $\left.200^{\circ} \mathrm{C}\right)$ & $\begin{array}{c}\text { To measure } \\
\text { temperature of water }\end{array}$ \\
\hline $\begin{array}{l}\text { Total Dissolved } \\
\text { Solid meter }\end{array}$ & Hanna HI 96301 with ATC & $\begin{array}{l}\text { To measure Total dissolved } \\
\text { solids in water }\end{array}$ \\
\hline Water sampler & Gallenkampf $1000 \mathrm{ml}$ & $\begin{array}{l}\text { To collect well water } \\
\text { sample from well }\end{array}$ \\
\hline Sample bottles & Polystyrene $500 \mathrm{ml}$ & $\begin{array}{l}\text { To hold sample for onward } \\
\text { transmission to laboratory }\end{array}$ \\
\hline ArcGIS & Version 10.1 & $\begin{array}{c}\text { GIS Drawing sampling/Tests } \\
\text { location maps }\end{array}$ \\
\hline Global Mapper & Version 15 & GIS Geolocation of wells \\
\hline Surfer Golden Software & Version 12 & $\begin{array}{l}\text { GIS plotting contours } \\
\text { for spatial distribution }\end{array}$ \\
\hline AqQA/Aquachem & Version 1.5 & $\begin{array}{c}\text { For the analysis/interpretation of } \\
\text { water chemistry }\end{array}$ \\
\hline
\end{tabular}




\subsection{Methods}

A reconnaissance survey was carried out to identify wells, springs, and streams in June 2016 as per [8]. Seasonal tests/measurements were carried out in September 2016 wet season and Dry season February 2017 respectively. 212 dug wells, were measured/tested in situ for: coordinates of wells, Surface elevation, Well water level, Dug wells depths, well diameter, Electrical conductivity (EC), $\mathrm{pH}$, Total dissolved solids (TDS) and Temperature $\left({ }^{\circ} \mathrm{C}\right)$. Forty (40) groundwater samples 20 in wet and dry seasons were collected in a high density polyethylene (HPDE) $500 \mathrm{ml}$ bottles sealed and sent to the laboratory as per sampling protocols; [9] [10] using the standard methods of [11] to analyze for:

1) Major cations in mg/L: $\mathrm{Ca}^{2+}, \mathrm{Mg}^{2+}, \mathrm{Na}^{+}, \mathrm{K}^{+}$and $\mathrm{NH}_{4}^{+}$;

2) Major anions in mg/L: $\mathrm{HCO}_{3}^{-}, \mathrm{Cl}^{-}, \mathrm{SO}_{4}^{2-}, \mathrm{HPO}_{4}{ }^{2-}$ and $\mathrm{NO}_{3}^{-}$.

Ionic ratio for indicative elements is a useful hydrogeochemical tool to identify source rock of ions and formation contribution to solute hydrogeochemistry [12]. These were used in this study.

Gibbs Diagram is a plot of $\mathrm{Na}^{+} /\left(\mathrm{Na}^{+}+\mathrm{HCO}_{3}^{-} \mathrm{Ca}^{2+}\right)$ and $\mathrm{Cl} /\left(\mathrm{Cl}+\mathrm{HCO}_{3}^{-}\right)$ as a function of TDS is widely employed to determine the sources of dissolved geochemical constituents. These plots reveal the relationships between water composition and the three main hydrogeochemical processes involved in ions acquisition; Atmospheric precipitation, rock weathering or evaporation crystallisation.

Pipers Diagram is a graphical representation of the chemistry of water sample on three fields; the cation ternary field with $\mathrm{Ca}, \mathrm{Mg}$ and $\mathrm{Na}+\mathrm{K}$ apices, the anion ternary field with $\mathrm{HCO}_{3}, \mathrm{SO}_{4}$ and $\mathrm{Cl}^{-}$apices. These two fields are projected onto a third diamond field. The diamond field is a matrix transformation of the graph of the anions [sulphate + chloride] $/ \Sigma$ anions and cations $[\mathrm{Na}+\mathrm{K}] / \Sigma$ cations. This plot is a useful hydrogeochemical tool to compare water samples, determine water type and hydrogeochemical facies [13]. This has been used here for these purposes.

Durov diagram is a composite plot consisting of two ternary diagrams where the milliequivalent percentages of cations are plotted perpendicularly against those of anions; the sides of the triangles form a central rectangular binary plot of total cation vs. total anion concentrations. These are divided into nine classes by [14] which give the hydrogeochemical processes determining the character of the water types in the aquiferous formation [13].

WQI was calculated by adopting Weighted Arithmetical Index method considering thirteen water quality parameters ( $\mathrm{pH}, \mathrm{EC}, \mathrm{TDS}$, total alkalinity, total hardness, $\mathrm{Ca}^{2+}, \mathrm{Mg}^{2+}, \mathrm{Na}^{+}, \mathrm{K}^{+}, \mathrm{Cl}^{-}, \mathrm{SO}_{4}^{2-}, \mathrm{NO}_{3}^{-}, \mathrm{NH}_{4}^{+}$) in order to assess the degree of groundwater contamination and suitability using indices and formulae in Table 2.

For Agro-industrial suitability the following parameters were used; sodium adsorption ratio SAR, permeability index PI, Magnesium adsorption ratio MAR, percent sodium \%Na, Kelly's ratio KR and Residual sodium carbonate RSC and 
Wilcox Diagram (Table 2).

The following softwares: Surfer 12, Global mapper 11 and AqQA 1.5 AGIS 10.3 were used for data presentation, interpretation, and analysis.

\section{Results and Interpretation}

\subsection{Physicochemical Parameters}

The physicochemical parameters of groundwater in Douala: Temperature, $\mathrm{pH}$, EC and TDS for 212 wells evaluated as demonstrated in Table 3. All physicochemical parameters vary with seasons indicating seasonal influence on the phreatic aquifer.

Table 2. Indices used in the calculation of water quality and irrigation water quality.

\begin{tabular}{|c|c|c|}
\hline & Formula & Reference \\
\hline Percentage of Sodium & $\% \mathrm{Na}=\frac{\mathrm{Na}^{+}+\mathrm{K}^{+}}{\mathrm{Na}^{+}+\mathrm{K}^{+}+\mathrm{Ca}^{2+}+\mathrm{Mg}^{2+}} \times 100$ & [15] \\
\hline Kelly's Ratio & $\mathrm{KR}=\frac{\mathrm{Na}^{+}}{\mathrm{Ca}^{2+}+\mathrm{Mg}^{2+}}$ & [16] \\
\hline $\begin{array}{c}\text { Magnesium } \\
\text { Adsorption Ratio }\end{array}$ & $\operatorname{MAR}=\left(\frac{\mathrm{Mg}^{2+}}{\mathrm{Mg}^{2+}+\mathrm{Ca}^{2+}}\right) \times 100$ & [17] \\
\hline Total Hardness & $\mathrm{TH}\left(\mathrm{CaCO}_{3}\right) \mathrm{mg} / \mathrm{L}=2.5 \mathrm{Ca}^{2+}+4.1 \mathrm{Mg}^{2+}$ & [18] \\
\hline $\begin{array}{l}\text { Residual Sodium } \\
\text { Carbonate }\end{array}$ & $\mathrm{RSC}=\left(\mathrm{CO}_{3}+\mathrm{HCO}_{3}-(\mathrm{Ca}+\mathrm{Mg})\right)$ & [19] \\
\hline $\begin{array}{c}\text { Sodium Adsorption } \\
\text { Ratio }\end{array}$ & $\mathrm{SAR}=\frac{\mathrm{Na}}{\sqrt{\frac{\mathrm{Ca}+\mathrm{Mg}}{2}}}$ & [20] \\
\hline Permeability Index & $\mathrm{PI}=\frac{\left((\mathrm{Na}+\mathrm{K})+\sqrt{\mathrm{HCO}_{3}}\right) \times 100}{\mathrm{Ca}+\mathrm{Mg}+\mathrm{Na}+\mathrm{K}}$ & {$[21][25]$} \\
\hline Water Quality Index & $\mathrm{WQI}=\sum_{i=1}^{n} W_{i} q_{i}\left[\sum_{i=1}^{n} W_{i}\right]$ & [22] \\
\hline
\end{tabular}

Table 3. Basic Statistics of the physicochemical parameters in groundwater, for both the wet season and dry seasons.

\begin{tabular}{ccccccccc}
\hline Parameters & \multicolumn{4}{c}{ Wet } & \multicolumn{5}{c}{ Dry } \\
\hline & Min & Max & Mean & Std. & Min & Max & Mean & Std. \\
\hline $\mathrm{T}\left({ }^{\circ} \mathrm{C}\right)$ & 26.3 & 29 & 27.4 & 0.51 & 24.4 & 29.6 & 28.52 & 0.66 \\
$\mathrm{PH}$ & 4.6 & 7.1 & 6.13 & 0.57 & 5.5 & 7.2 & 6.35 & 0.51 \\
$\mathrm{EC}(\mathrm{mS} / \mathrm{cm})$ & 0.02 & 1.63 & 0.5 & 0.29 & 0.01 & 1.61 & 0.36 & 0.28 \\
$\mathrm{TDS}(\mathrm{mg} / \mathrm{L})$ & 0.01 & 1.09 & 0.33 & 0.19 & 0.01 & 1.08 & 0.24 & 0.19 \\
\hline
\end{tabular}




\subsubsection{Water Level Fluctuations}

Depth-to statues water values $(\mathrm{m})$ of groundwater in Douala ranged from 0.12 10.13 in the Wet season and $0.32-8.2$ in the dry season as in Figure 3.

\subsubsection{Groundwater Flow Direction}

Groundwater flows towards the central parts of the study area during the wet season and dry season but during the dry season some water flows towards the Northwestern part as in Figure 4.

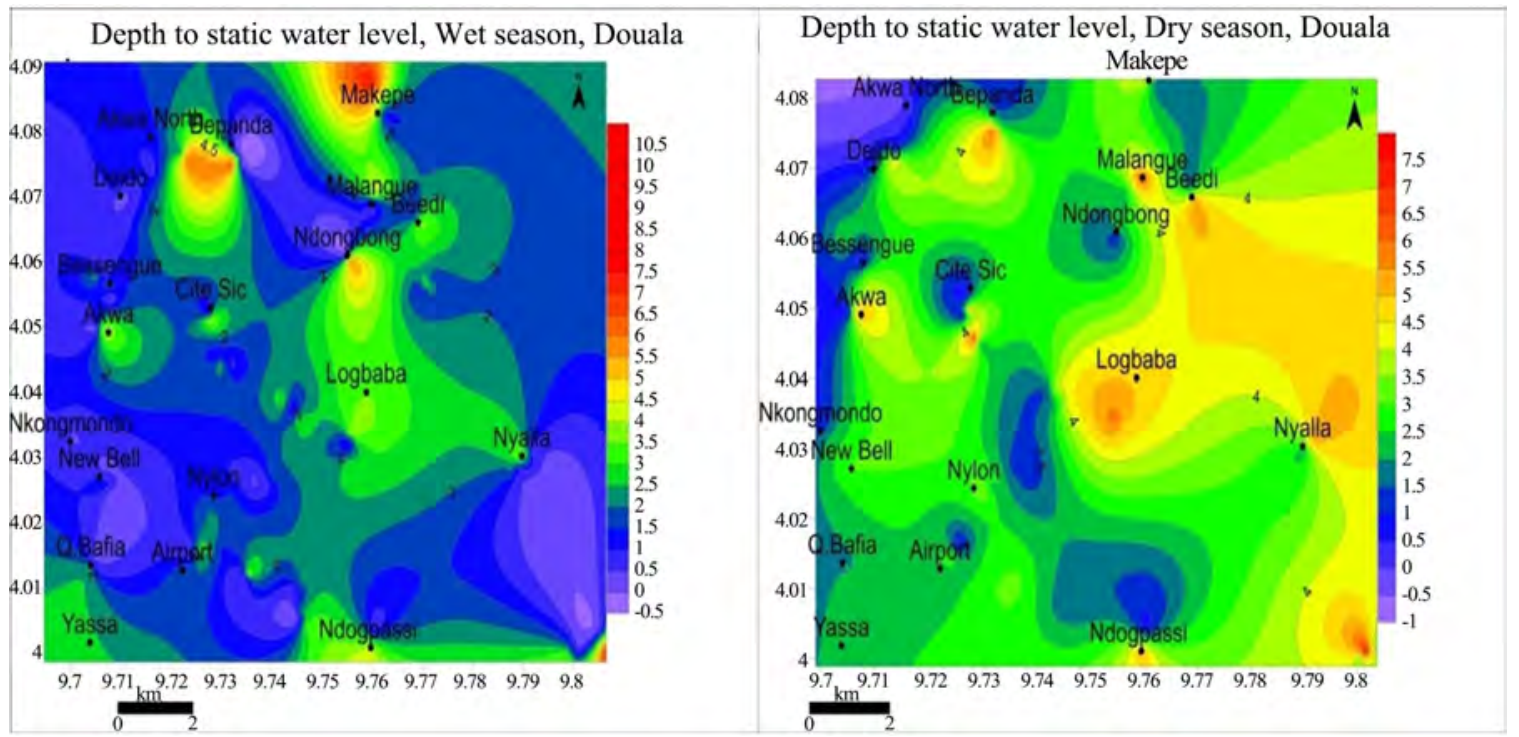

Figure 3. Depth to static water level in Douala; note highwater level is recorded during the wet season than in the dry season. High values are at Makepe and Bepanda in the wet season with high values at Logbaba and Nyalla during the dry season. Low values are at Airport, Nkongmondo and Akwa North for both seasons.

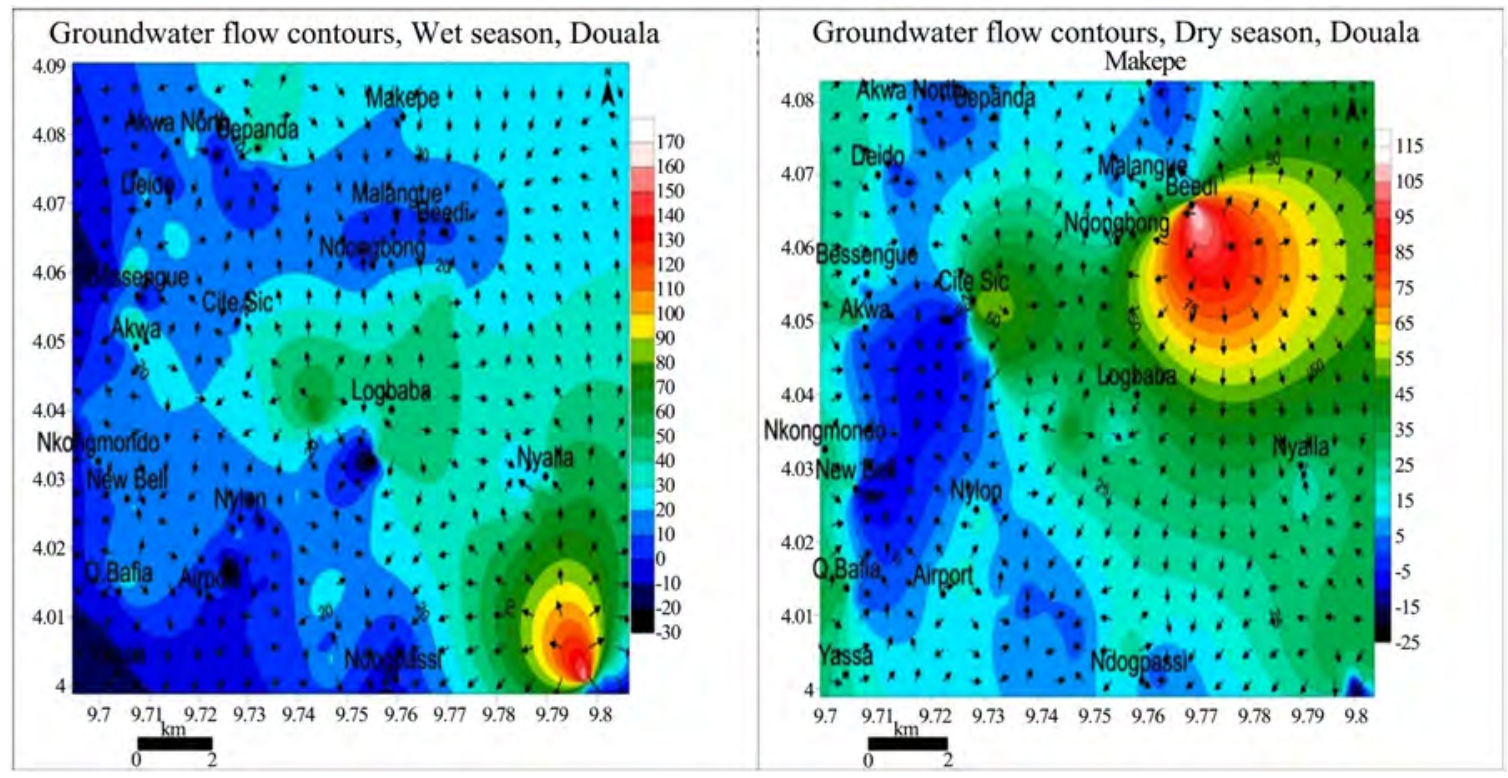

Figure 4. Groundwater flow direction in Douala indicating that water flows towards the Central part of the study area that is towards Malengue, Beedi, and Ndongbong in the wet season but during the dry season some water flows towards Northwestern parts indicating that it is a recharge zone. 


\subsubsection{Temperature}

Temperature values ${ }^{\circ} \mathrm{C}$ ranged from 26.3 - 29 in the wet season and $24.4^{\circ} \mathrm{C}$ $29.6^{\circ} \mathrm{C}$ in the dry season as in Figure 5.

\subsection{4. $\mathrm{pH}$}

The $\mathrm{pH}$ value of the groundwater samples in the study area ranged from 4.6 - 7.1 in the wet season and $5-7.2$ in the dry season as in Figure 6. This clearly shows that the groundwater in the study area is acidic to alkaline.

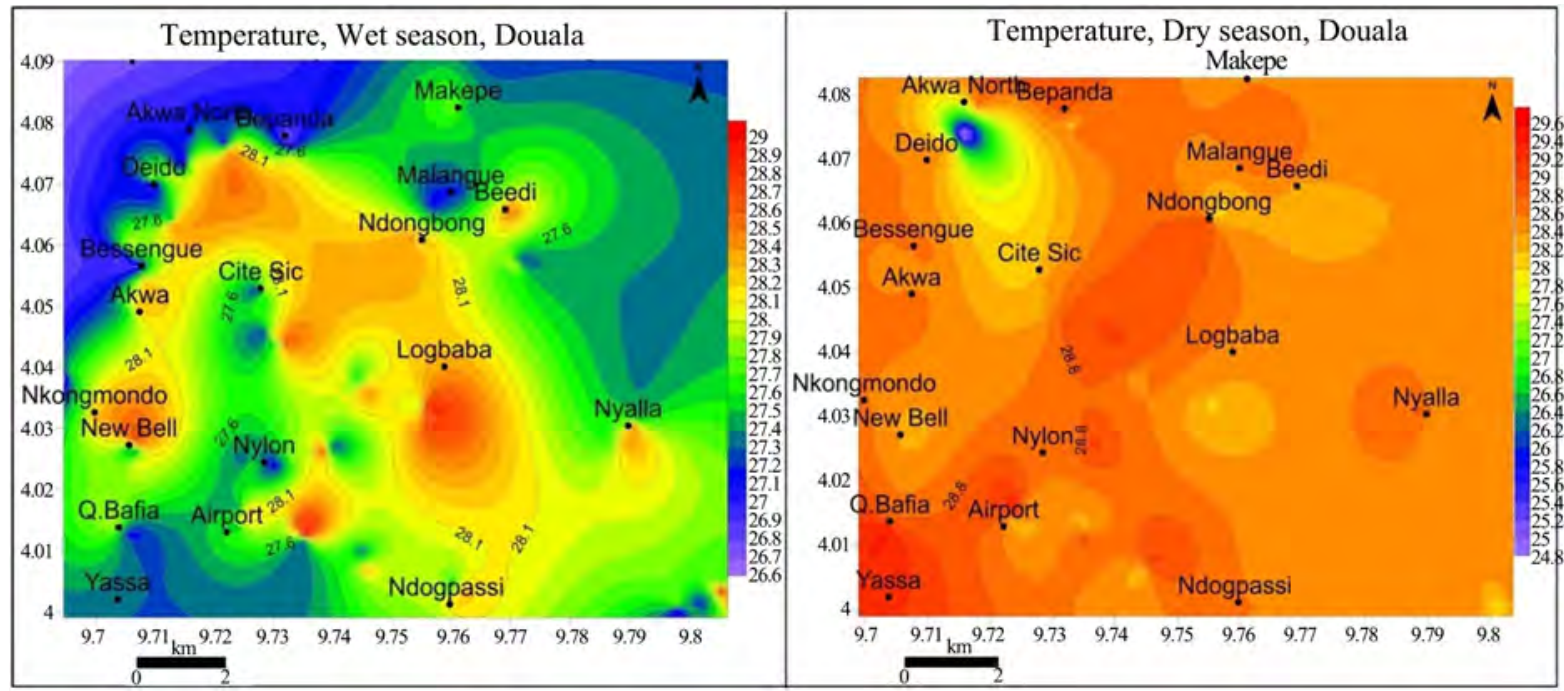

Figure 5. Variation of Douala groundwater temperature; temperatures are generally higher in the dry season and lower in the wet season. High temperatures are in Logbaba, New Bell and Beedi while low values are at Akwa North and Malangu in the wet season and during the dry season, the highest values are found Yassa and Bepanda.

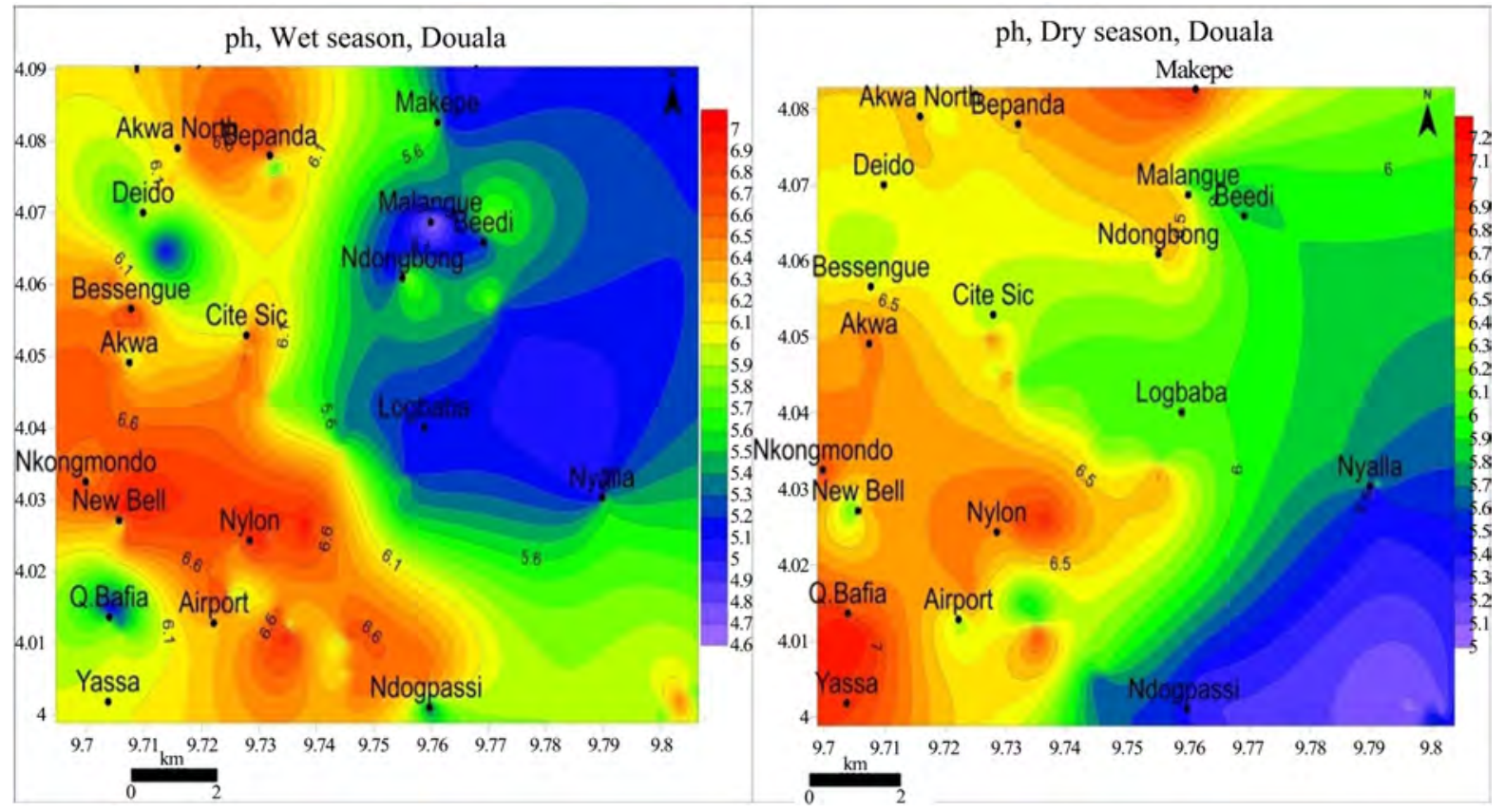

Figure 6. Spatial variation of $\mathrm{pH}$; note decrease in $\mathrm{pH}$ values wet season around Nyalla and Logbaba while in the dry seasons the $\mathrm{pH}$ values increases around QuatierBafia, Yassa and Makepe. 


\subsubsection{Electrical Conductivity}

The EC ranges from $0.02-1.63 \mathrm{mS} / \mathrm{cm}$ during the wet season and $0.01-1.61$ $\mathrm{mS} / \mathrm{cm}$ during the dry season as in Figure 7. The high electrical conductivity is due to high solute concentration in water.

\subsubsection{Total Dissolved Solids (TDS)}

The total dissolved solids range from $0.02-1.09 \mathrm{mg} / \mathrm{L}$ in the wet season and 0.01 $1.08 \mathrm{mg} / \mathrm{L}$ in the dry seasons in Figure 8.

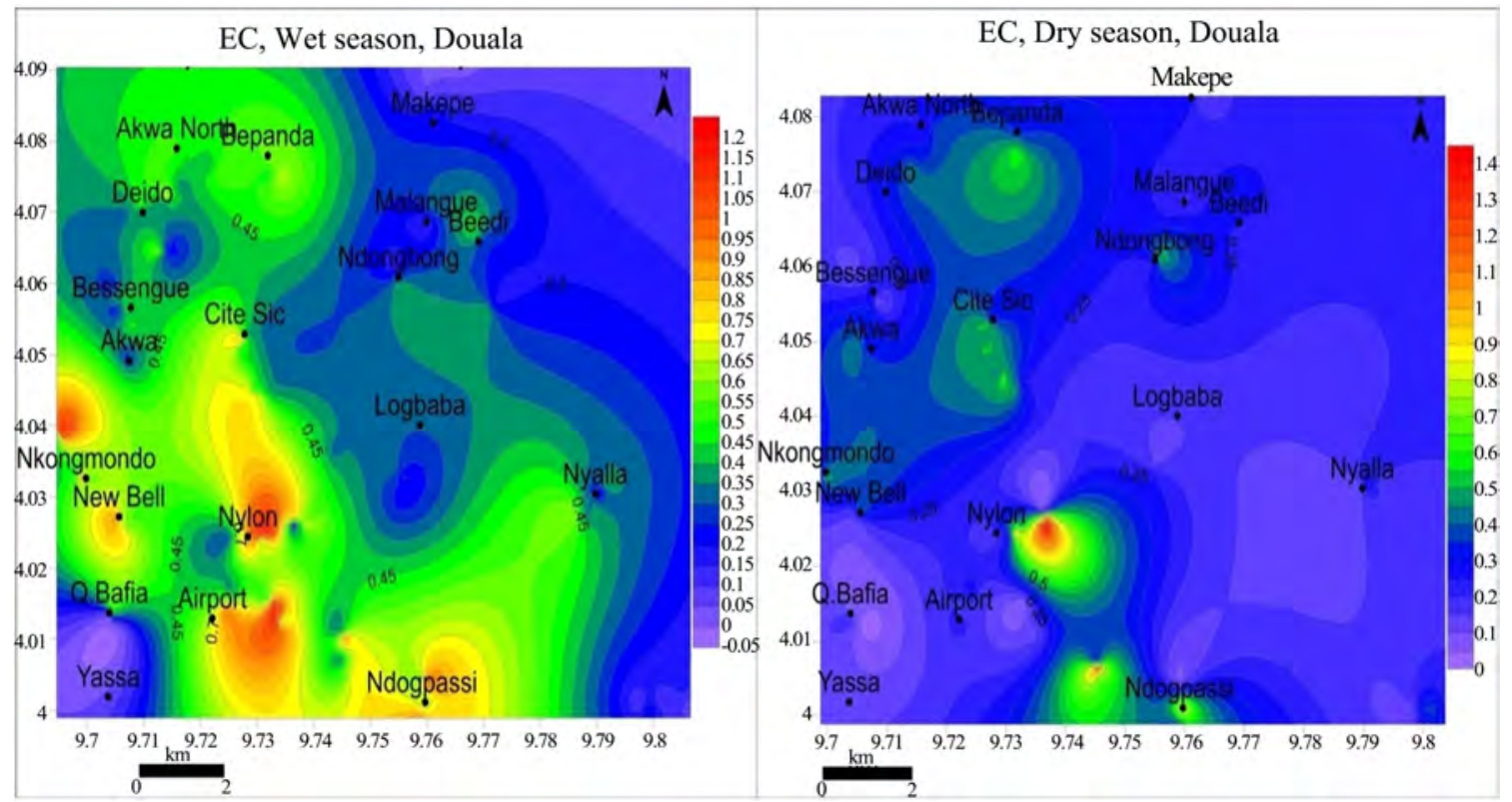

Figure 7. Spatial variation of Electrical Conductivities $(\mathrm{mS} / \mathrm{cm})$; EC is at maximum in the wet season and minimum in the dry season.

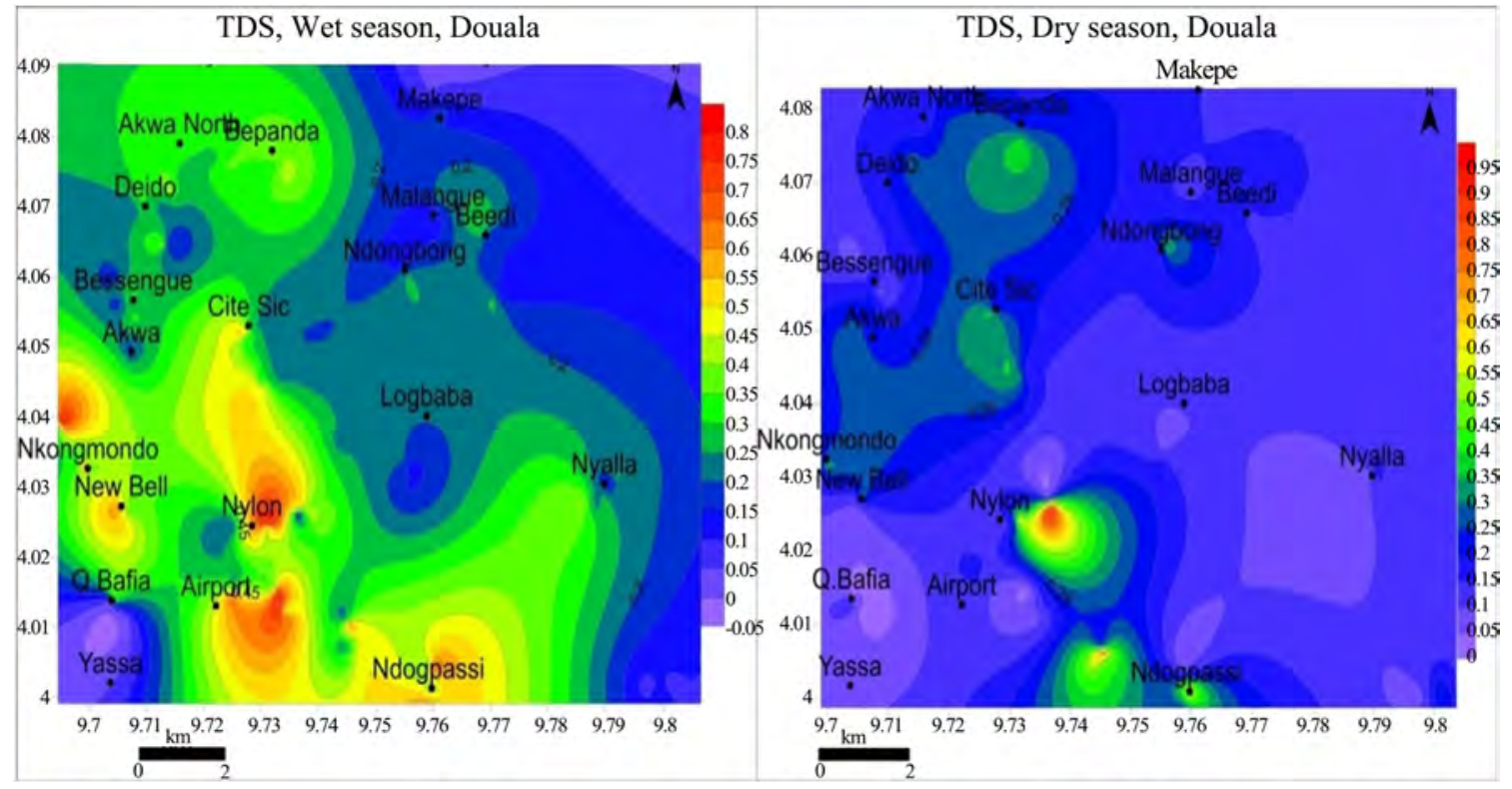

Figure 8. Spatial variation of total dissolved solids $\mathrm{mg} / \mathrm{L}$ in Douala during wet and dry season. TDS is highest in the wet season and lowest in the dry season. In the wet season, the highest value is at Nylon and Airport. 


\subsection{Chemical Parameters of Groundwater}

The results of the chemical analysis varied in both seasons as shown in Table 4(a) and Table 4(b). Wet season the trend was $\mathrm{Ca}^{2+}>\mathrm{Mg}^{2+}>\mathrm{K}^{+}>\mathrm{NH}_{4}^{+}>\mathrm{Na}^{+}$ for cations and $\mathrm{HCO}_{3}^{-}>\mathrm{Cl}^{-}>\mathrm{SO}_{4}^{2-}>\mathrm{NO}_{3}^{-}>\mathrm{HPO}_{4}^{2-}$ for anions.

Dry season: The trend was $\mathrm{Ca}^{2+}>\mathrm{Mg}^{2+}>\mathrm{K}^{+}>\mathrm{Na}^{+}>\mathrm{NH}_{4}^{+}$for cations and $\mathrm{HCO}_{3}^{-}>\mathrm{Cl}^{-}>\mathrm{SO}_{4}^{2-}>\mathrm{HPO}_{4}^{2-}>\mathrm{NO}_{3}^{-}$for anions.

Table 4. (a) Results of chemical analysis during wet season; (b) Results of chemical analysis during dry season.

(a)

\begin{tabular}{|c|c|c|c|c|c|c|c|c|c|c|c|}
\hline \multicolumn{12}{|c|}{ Wet Season $(\mathrm{mg} / \mathrm{L})$} \\
\hline SN & Location & $\mathrm{Na}^{+}$ & $\mathrm{K}^{+}$ & $\mathrm{Ca}^{2+}$ & $\mathrm{Mg}^{2+}$ & $\mathrm{NH}_{4}^{+}$ & $\mathrm{HCO}_{3}^{-}$ & $\mathrm{NO}_{3}^{-}$ & $\mathrm{SO}_{4}^{2-}$ & $\mathrm{CL}^{-}$ & $\mathrm{HPO}_{4}^{2-}$ \\
\hline 1 & Quartier Bafia & 0 & 1.25 & 0 & 1.25 & 0 & 67.1 & 11.1 & 3.23 & 2 & 0 \\
\hline 2 & Airport & 0.51 & 5.81 & 12.4 & 7.43 & 0 & 89.67 & 6.59 & 17.87 & 26 & 0 \\
\hline 3 & Nylon & 2.24 & 30.65 & 90 & 12.98 & 0 & 121.39 & 6.75 & 22.5 & 110 & 0.17 \\
\hline 4 & Ndogpassi 1 & 2.3 & 26.95 & 83.8 & 20.76 & 0 & 200.69 & 8.61 & 27.5 & 106 & 0.17 \\
\hline 5 & Ndogpassi 3 & 1.66 & 21.68 & 55.8 & 18.71 & 0 & 216.55 & 7.67 & 23.62 & 46 & 0 \\
\hline 6 & Yassa & 0.23 & 2.81 & 0 & 2.11 & 0 & 0 & 10.11 & 2.53 & 6 & 0.93 \\
\hline 7 & Nyalla & 0.23 & 2.46 & 0 & 1.5 & 0 & 0 & 3.31 & 3.09 & 24 & 0 \\
\hline 8 & Logbaba & 0.41 & 4.76 & 3.1 & 7.1 & 5.39 & 0 & 5.39 & 5.8 & 20 & 0 \\
\hline 9 & Cite Sic & 0.83 & 10.06 & 24.8 & 1.84 & 7.64 & 0 & 5.69 & 6.69 & 42 & 0.51 \\
\hline 10 & Ndongbong & 0.74 & 8.58 & 18.6 & 14.1 & 14.2 & 0 & 4.43 & 8.61 & 36 & 0 \\
\hline 11 & Beedi & 0.51 & 6.01 & 12.4 & 11.31 & 7.1 & 0 & 4.89 & 7.62 & 26 & 0 \\
\hline 12 & Malangue & 0.28 & 3.16 & 3.1 & 2.71 & 0 & 0 & 4.04 & 1.92 & 28 & 0 \\
\hline 13 & Makepe & 0.41 & 7.41 & 18.62 & 3.88 & 0 & 10.37 & 5.02 & 9.17 & 10 & 0 \\
\hline 14 & Bessengue & 0.55 & 7.41 & 12.4 & 2.06 & 1.44 & 45.75 & 3.95 & 9.87 & 24 & 0 \\
\hline 15 & Akwa & 0.74 & 8.46 & 18.6 & 4.9 & 4.76 & 71.37 & 2.58 & 11.37 & 48 & 0 \\
\hline 16 & Akwa North & 0.05 & 1.76 & 0 & 1.76 & 0 & 20.13 & 4.55 & 2.9 & 6 & 0 \\
\hline 17 & Deido & 0.64 & 7.22 & 15.6 & 14 & 4.34 & 0 & 3.92 & 2.62 & 42 & 3.06 \\
\hline 18 & NkongMondo & 1.06 & 12.68 & 34.2 & 10.51 & 0 & 87.23 & 6.29 & 11.27 & 32 & 0 \\
\hline 19 & New Bell & 1.43 & 17.08 & 46.6 & 32.09 & 0 & 73.81 & 5.99 & 27.55 & 48 & 0.25 \\
\hline \multirow[t]{5}{*}{20} & Bonamoussadi & 0 & 0.2 & 0 & 1.51 & 0 & 33.55 & 2.24 & 2.34 & 4 & 0 \\
\hline & $\min$ & 0 & 0.2 & 0 & 1.25 & 0 & 0 & 2.24 & 1.92 & 2 & 0 \\
\hline & $\max$ & 2.3 & 30.65 & 90 & 32.09 & 14.2 & 216.55 & 11.1 & 27.55 & 110 & 3.06 \\
\hline & mean & 0.74 & 9.32 & 22.50 & 8.63 & 2.24 & 51.88 & 5.66 & 10.40 & 34.3 & 0.25 \\
\hline & std & 0.68 & 8.52 & 26.98 & 8.26 & 3.86 & 65.89 & 2.34 & 8.69 & 29.25 & 0.700 \\
\hline
\end{tabular}


(b)

\begin{tabular}{|c|c|c|c|c|c|c|c|c|c|c|c|}
\hline \multicolumn{12}{|c|}{ Dry Season $(\mathrm{mg} / \mathrm{L})$} \\
\hline SN & Location & $\mathrm{Na}^{+}$ & $\mathrm{K}^{+}$ & $\mathrm{Ca}^{2+}$ & $\mathrm{Mg}^{2+}$ & $\mathrm{NH}_{4}^{+}$ & $\mathrm{HCO}_{3}^{-}$ & $\mathrm{NO}_{3}^{-}$ & $\mathrm{SO}_{4}^{2-}$ & $\mathrm{CL}^{-}$ & $\mathrm{HPO}_{4}^{2-}$ \\
\hline 1 & Quartier Bafia & 0.24 & 2.39 & 16 & 14.25 & 0 & 144.3 & 0 & 0 & 0 & 0 \\
\hline 2 & Airport & 0.65 & 5.9 & 15 & 34.51 & 0 & 74.84 & 0.01 & 17.33 & 8 & 0 \\
\hline 3 & Nylon & 1.54 & 28.45 & 95 & 41.17 & 0 & 142.3 & 0.01 & 19.84 & 63 & 0.01 \\
\hline 4 & Ndogpassi 1 & 1.3 & 27.13 & 98.3 & 24.1 & 0 & 130 & 0.02 & 21.88 & 52 & 0.01 \\
\hline 5 & Ndogpassi 2 & 1.25 & 20.24 & 80.2 & 26.71 & 0 & 153.71 & 0 & 20.45 & 18 & 0 \\
\hline 6 & Yassa & 0.51 & 3.44 & 14 & 16.94 & 0 & 148.84 & 0.03 & 0.65 & 0 & 0.42 \\
\hline 7 & Nyalla & 0.52 & 4.03 & 13 & 14 & 0 & 132.11 & 0 & 0.04 & 23 & 0 \\
\hline 8 & Logbaba & 0.62 & 6.23 & 25.01 & 35.19 & 0.13 & 100 & 0.01 & 0.41 & 15 & 0 \\
\hline 9 & Cite Sic & 0.91 & 11.65 & 20.25 & 23.04 & 0.11 & 0 & 0.03 & 0.54 & 18 & 0.32 \\
\hline 10 & Ndongbong & 0.64 & 7.81 & 15.14 & 12.64 & 0.25 & 0 & 0.02 & 1.35 & 17 & 0 \\
\hline 11 & Beedi & 0.41 & 5.11 & 5.77 & 6.88 & 0.12 & 0 & 0 & 1.25 & 10 & 0 \\
\hline 12 & Malangue & 0.35 & 5.21 & 23.41 & 12.44 & 0 & 9 & 0 & 0 & 12 & 0 \\
\hline 13 & Makepe & 0.64 & 10.05 & 20.34 & 14.52 & 0 & 0 & 0 & 9.45 & 3 & 0 \\
\hline 14 & Bessengue & 0.68 & 11.14 & 15.09 & 4.85 & 0 & 0 & 0.01 & 11.01 & 8 & 0 \\
\hline 15 & Akwa & 0.96 & 10.24 & 20.23 & 7.09 & 0.11 & 19.24 & 0.01 & 10.11 & 35 & 0 \\
\hline 16 & Akwa North & 0.1 & 2.79 & 18 & 2.35 & 0 & 24.15 & 0 & 0 & 2 & 0 \\
\hline 17 & Deido & 0.45 & 6.13 & 15.94 & 14.17 & 0.13 & 18.99 & 0 & 0 & 32 & 2.77 \\
\hline 18 & NkongMondo & 1 & 11.45 & 32.04 & 9.44 & 0 & 160.24 & 0.02 & 11.03 & 24 & 0 \\
\hline 19 & New Bell & 1.8 & 18.04 & 48.24 & 35.03 & 0 & 162.84 & 0.01 & 24.03 & 12.31 & 0.12 \\
\hline \multirow[t]{5}{*}{20} & Bepanda & 0.39 & 0.34 & 13 & 15.09 & 0 & 0 & 0.01 & 0 & 0 & 0 \\
\hline & $\min$ & 0.1 & 0.34 & 5.77 & 2.35 & 0 & 0 & 0 & 0 & 0 & 0 \\
\hline & $\max$ & 1.8 & 28.45 & 98.3 & 41.17 & 0.25 & 162.84 & 0.03 & 24.03 & 63 & 2.77 \\
\hline & mean & 0.75 & 9.89 & 30.20 & 18.22 & 0.04 & 71.03 & 0.01 & 7.47 & 17.62 & 0.18 \\
\hline & std & 0.44 & 7.91 & 27.84 & 11.22 & 0.07 & 68.63 & 0.01 & 8.86 & 17.04 & 0.62 \\
\hline
\end{tabular}

\subsection{Mechanism Controlling Water Chemistry}

\subsubsection{Ionic Ratios of Groundwater in Douala}

18 ionic ratios in groundwater were used to deduce formation inputs in Douala, as shown in Table 5.

11 out of the $18(61.1 \%)$ ionic ratios calculated gave indices indicating rock weathering of formations as a source of solute concentration in the groundwater while nitrate ratio indicates no anthropogenic contribution and sulfate indices indicates no oxidation of sulfides. $\mathrm{Ca}$ is sourced from gypsum while $\mathrm{Na}$ is sourced from halite-albite and ion exchange. $\mathrm{Mg}$ is contributed by dolomite dissolution, calcite precipitation or saltwater. There is no plagioclase weathering. High indices values are found in the following localities Logbaba, Bepanda, Cite sic and Akwa North. 
Table 5. Ionic ratios for wet and dry seasons with determined formation input.

\begin{tabular}{|c|c|c|c|c|}
\hline Ionic ratio & Wet & Dry & Comment & Interpretation \\
\hline $\mathrm{SO}_{4} / \mathrm{Cl}$ & $0.06-1.62$ & $0-3.15$ & high & $\begin{array}{l}\text { Additional sources of } \mathrm{SO}_{4} \text { from } \\
\text { weathering of sulfates }\end{array}$ \\
\hline $\mathrm{Na} / \mathrm{Cl}$ & $0.00-0.04$ & $0-0.21$ & low & $\begin{array}{l}\text { No Na-adsorption during freshening } \\
\text { and a little silicate weathering }\end{array}$ \\
\hline $\mathrm{Mg} / \mathrm{Cl}$ & $0.04-0.67$ & $0-4.84$ & high & $\begin{array}{l}\text { Cation-exchange and silicate } \\
\text { weathering of sandstones. }\end{array}$ \\
\hline $\mathrm{Na} / \mathrm{HCO}_{3}$ & $0.00-0.04$ & $0-0.05$ & high & $\begin{array}{l}\text { Substantial weathering of } \mathrm{Na} \text {-feldspar } \\
\text { or other } \mathrm{Na} \text {-silicates }\end{array}$ \\
\hline $\mathrm{Ca} / \mathrm{HCO}_{3}$ & $0.00-1.80$ & $0-2.60$ & high & $\begin{array}{l}\text { Calc-carbonate dissolution or } \\
\text { Calc-silicate weathering }\end{array}$ \\
\hline $\mathrm{Ca} / \mathrm{SO}_{4}$ & $0.00-4.00$ & $3.84-61$ & high & Gypsum dissolution present \\
\hline $\mathrm{Ca} / \mathrm{Mg}$ & $0.00-13.48$ & $0-7.66$ & high & $\begin{array}{l}\text { Cation-exchange of weathering of } \\
\text { silicate rocks. }\end{array}$ \\
\hline $\mathrm{Ca}+\mathrm{Mg} / \mathrm{Na}+\mathrm{K}$ & $0.00-7.55$ & $0.00-38.48$ & high & Carbonate weathering \\
\hline $\mathrm{HCO}_{3} / \Sigma$ Anions & $0.00-0.11$ & $0.00-0.08$ & high & $\begin{array}{l}\text { Weathering reactions and input of } \\
\text { dissolved species in recharge area }\end{array}$ \\
\hline $\mathrm{NO}_{3} / \Sigma$ Anions & $0.00-0.01$ & $0.00-0.00$ & very low & No anthropogenic contribution \\
\hline $\mathrm{SO}_{4} / \Sigma$ Anions & $0.00-0.01$ & $0.00-0.01$ & very low & No oxidation of sulphides. \\
\hline $\mathrm{Mg} / \mathrm{Ca}$ & $0.00-2.29$ & $0.00-4.84$ & low & Weathering of Silicate rocks \\
\hline $\mathrm{Na} / \mathrm{Na}+\mathrm{Cl}$ & $0.00-0.04$ & $0.01-1.00$ & high & $\begin{array}{c}\text { Sodium source other than halite-albite, } \\
\text { ion exchange }\end{array}$ \\
\hline $\mathrm{Mg} / \mathrm{Ca}+\mathrm{Mg}$ & $0.07-1.00$ & $0.12-0.7$ & high & $\begin{array}{l}\text { Dolomite dissolution, calcite } \\
\text { precipitation or saltwater }\end{array}$ \\
\hline $\mathrm{Ca} / \mathrm{Ca}+\mathrm{SO}_{4}$ & $0.00-0.86$ & $0.46-1.00$ & high & Calcium source other than gypsum \\
\hline $\mathrm{Ca}+\mathrm{Mg} / \mathrm{SO}_{4}$ & $0.39-11.30$ & $0.00-675$ & & \\
\hline $\begin{array}{c}\mathrm{Na}+\mathrm{K}-\mathrm{Cl} / \mathrm{Na}+ \\
\mathrm{K}-\mathrm{Cl}+\mathrm{Ca}\end{array}$ & $0.10-1.00$ & $-0.61-0.61$ & high & Plagioclase weathering unlikely \\
\hline $\mathrm{Cl} / \Sigma$ Anions & $0.00-0.16$ & $0.00-0.04$ & low & Rock weathering \\
\hline
\end{tabular}

\subsubsection{Gibbs Diagrams of Groundwater in Douala}

The Gibbs diagrams were used. All samples plot in the rock-weathering dominance for both seasons. This indicates the mechanism contributing solute to groundwater in Douala is rock-weathering as in Figure 9.

\subsubsection{Groundwater Types}

The diamond field of piper diagram has further been divided into seven fields classifying water types and designated with alphabets from $A$ to $G$ according to [13]. Using this classification, the water from the study area is distinguished into the $\mathrm{A}, \mathrm{B}$, and $\mathrm{C}$ categories. The $\mathrm{D}, \mathrm{E}, \mathrm{F}$, and $\mathrm{G}$ water types are absent. In the rainy season; Category A, 2 samples 10\%; characterized by normal earth alkaline water with prevailing bicarbonate. Category B, 4 samples $20 \%$ are characterized by normal earth alkaline water with prevailing bicarbonate and sulfate or chlo- 
ride, Category C, 8 samples $40 \%$ are characterized by earth alkaline water with prevailing sulfate or chloride Category D, 2 samples $10 \%$ are characterized by earth alkaline water; increased portions of alkalis; prevailing $\mathrm{HCO}_{3}^{-}$and Category E, 4 samples $20 \%$ are characterized by earth alkaline water with added portions of alkalis with prevailing chloride as seen in Figure 10.

In the dry season; Category A, 10 samples $50 \%$ characterized by normal earth alkaline water with prevailing bicarbonate. Category B, 2 samples $10 \%$ are characterized by normal earth alkaline water with prevailing bicarbonate and sulfate or chloride, Category C, 7 samples $35 \%$ are characterized by earth alkaline water with prevailing sulfate or chloride and Category E 1 sample 5\% are characterized by earth alkaline water with added portions of alkalis with prevailing chloride as in Figure 10. The dominant water types are Category C, 40\%; Normal earth alkaline water; prevailing $\mathrm{SO}_{4}^{2-}$ or $\mathrm{Cl}^{-}$in the wet season and Category $\mathrm{A}, 50 \%$; Normal earth alkaline water; prevailing $\mathrm{HCO}_{3}^{-}$in the dry season. The water types in Douala groundwater are $\mathrm{MgCl}$ and $\mathrm{MgHCO}_{3}$ for both seasons seen in Table 6.

Table 6. Classification of Douala groundwater based on Piper diagram [13] to depict water types and hydrogeochemical facies.

\begin{tabular}{|c|c|c|c|c|c|}
\hline \multirow{2}{*}{ Class } & \multirow{2}{*}{ Water Types } & \multicolumn{2}{|c|}{ Wet } & \multicolumn{2}{|c|}{ Dry } \\
\hline & & No & $\%$ & No & $\%$ \\
\hline A & $\begin{array}{c}\text { Normal earth alkaline } \\
\text { water with prevailing bicarbonate }\end{array}$ & 2 & 10 & 10 & 50 \\
\hline B & $\begin{array}{l}\text { Normal earth alkaline water with prevailing } \\
\text { bicarbonate and sulfate or chloride }\end{array}$ & 4 & 20 & 2 & 10 \\
\hline $\mathrm{C}$ & $\begin{array}{l}\text { Normal earth alkaline water with } \\
\text { prevailing Sulfate or Chloride }\end{array}$ & 8 & 40 & 7 & 35 \\
\hline $\mathrm{D}$ & $\begin{array}{l}\text { Earth alkaline water; increased portions } \\
\text { of alkalis; prevailing } \mathrm{HCO}_{3}^{-}\end{array}$ & 2 & 10 & & \\
\hline E & $\begin{array}{l}\text { Earth alkaline water with added portions of } \\
\text { alkalis with prevailing chloride }\end{array}$ & 4 & 20 & 1 & 5 \\
\hline \multicolumn{6}{|c|}{ Cations field } \\
\hline 1 & Calcium rich & 8 & 40 & 8 & 40 \\
\hline 2 & Magnesium rich & 12 & 60 & 12 & 60 \\
\hline \multicolumn{6}{|c|}{ Anion Field } \\
\hline 4 & Bicarbonate rich & 8 & 40 & 12 & 60 \\
\hline 5 & Chloride rich & 12 & 60 & 6 & 30 \\
\hline 6 & Sulfate rich & & & 2 & 10 \\
\hline \multicolumn{6}{|c|}{ Hydrogeochemical facies } \\
\hline Field I & $\mathrm{Ca}-\mathrm{Mg}-\mathrm{Cl}-\mathrm{SO}_{4}$ & 14 & 70 & 7 & 35 \\
\hline Field IV & $\mathrm{Ca}-\mathrm{Mg}-\mathrm{HCO}_{3}$ & 6 & 30 & 13 & 65 \\
\hline
\end{tabular}




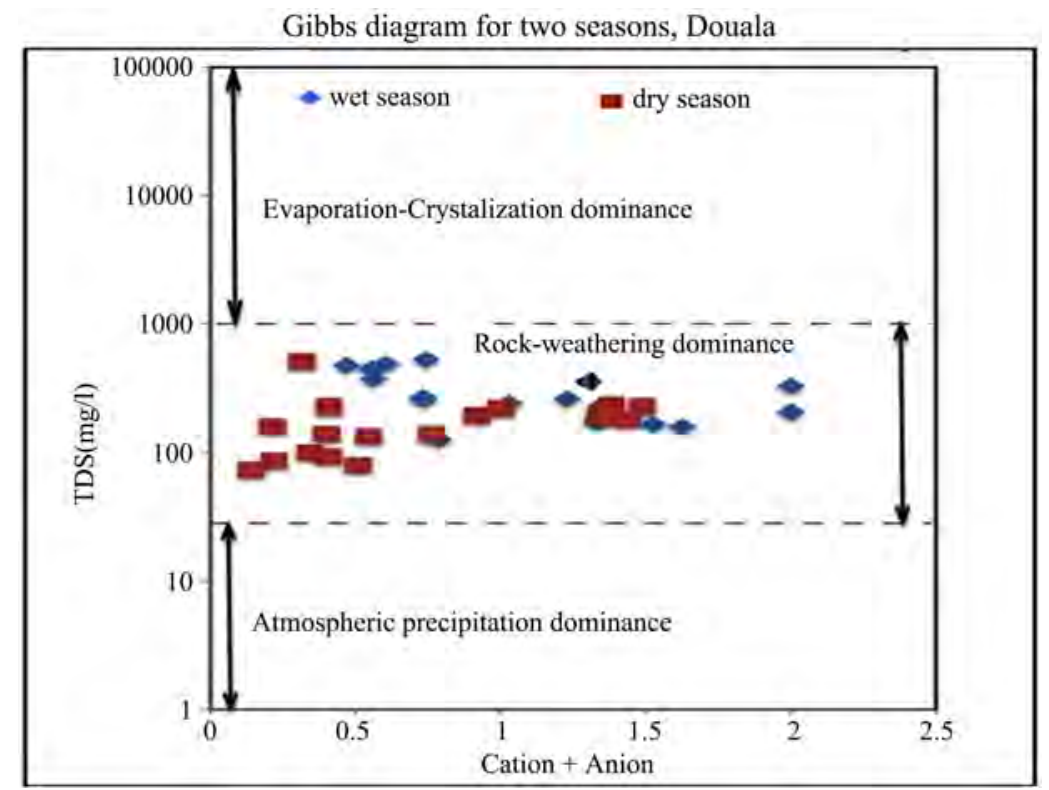

Figure 9. Gibbs diagram for Douala groundwater [23]: In both the wet and dry season all samples plot in the rock-weathering dominance field indicating that rock weathering is the mechanism controlling chemical composition of groundwater in the study area.

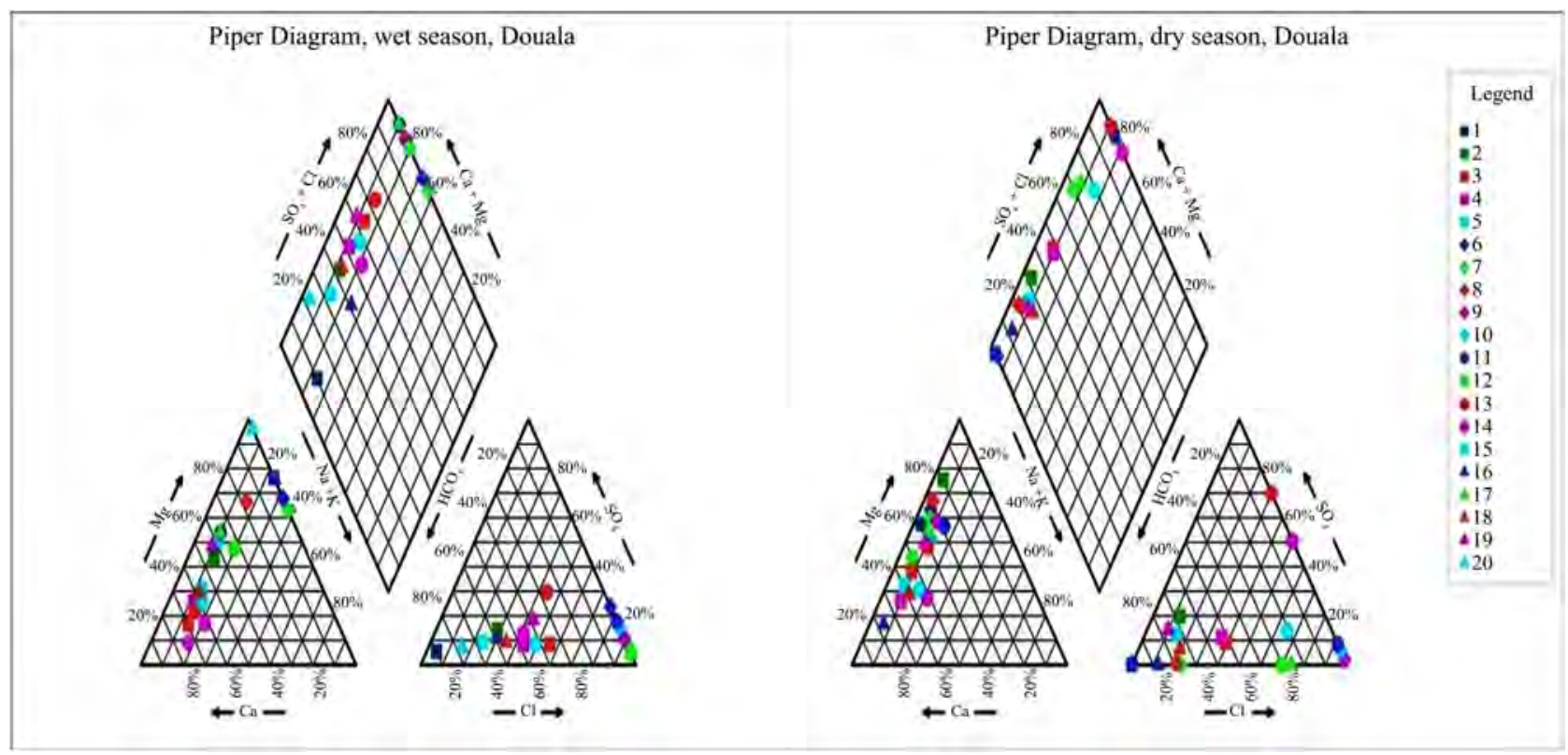

Figure 10. Piper's diagrams [24] for Douala groundwater samples.

Diamond field I: Ca-Mg-Cl-SO ${ }_{4}$ hydrogeochemical facies has 14 samples, $70 \%$ in the rainy and 7 samples, $35 \%$ in the dry season. Field IV, $\mathrm{Ca}-\mathrm{Mg}-\mathrm{HCO}_{3}$ hydrogeochemical facies has 6 samples, 30\% in the rainy and 13 samples, $65 \%$ in the dry season. No samples plotted on field II and field III in both seasons [13].

\subsubsection{Hydrogeochemical Facies}

From Piper's diagrams, the field I: Ca-Mg- $\mathrm{Cl}^{-}-\mathrm{SO}_{4}$ hydrogeochemical facies has 14 samples, $70 \%$ in the rainy and 7 samples, $35 \%$ in the dry season demonstrat- 
ing the dominance of alkaline earths over alkali $\mathrm{Ca}+\mathrm{Mg}>\mathrm{Na}+\mathrm{K}$ and strong acidic anions over weak acidic anions. Field IV, $\mathrm{Ca}-\mathrm{Mg}-\mathrm{HCO}_{3}$ hydrogeochemical facies has 6 samples, 30\% in the rainy and 13 samples, $65 \%$ in the dry season as shown in Table 7. This facies is characteristic of freshly recharged groundwater that has equilibrated with $\mathrm{CO}_{2}$ and soluble carbonate minerals under open system conditions in the vadose zone typical of shallow groundwater flow systems in crystalline phreatic aquifers.

No samples plotted on field II and field III.

\subsubsection{Durov Diagrams}

Based on the classification of [14]: Six classes of processes occur in the rainy season; Class 1 recharging waters: 10 samples, 50\%; Class 2 ion exchange water: 5 samples, 15\%; Class 3 ion exchange water: 1 sample, 5\%; Class 4: mixed water or water exhibiting simple dissolution: 7 samples, 35\%, Class 5 simple dissolution or mixing: 4 samples, $20 \%$ and Class 6 probable mixing or uncommon dissolution influences: 2 samples, $10 \%$ respectively as shown in Table 7. Six classes of processes occur in the dry season: Class 1 recharging waters: 1 sample 5\%; Class 2 ion exchange water: 2 sample 10\%; Class 3 ion exchange water: 3 samples $15 \%$; Class $4630 \%$ mixed water or water exhibiting simple dissolution may be indicated; Class 5 simple dissolution or mixing: 1 sample 5\%; Class 6 probable mixing or uncommon dissolution influences: 7 samples 35\% respectively as in Figure 11. There are no Classes 7, 8 and 9 in both seasons.

Table 7. Classification of Water based on Durov diagram.

\begin{tabular}{|c|c|c|c|c|c|}
\hline \multirow[b]{2}{*}{$\mathrm{SN}$} & \multirow[b]{2}{*}{ Description of Water Types } & \multicolumn{2}{|c|}{ Wet } & \multicolumn{2}{|c|}{ Dry } \\
\hline & & No & $\%$ & No & $\%$ \\
\hline 1 & $\begin{array}{l}\mathrm{HCO}_{3} \text { and Ca dominant, frequently indicates recharging } \\
\text { waters in limestone, sandstone, and many other aquifers }\end{array}$ & 1 & 5 & 1 & 5 \\
\hline 2 & $\begin{array}{l}\text { This water type is dominated by } \mathrm{Ca} \text { and } \mathrm{HCO}_{3} \text { ions. } \\
\text { Association with dolomite is presumed if } \mathrm{Mg} \text { is } \\
\text { significant. However, those samples in which } \mathrm{Na} \text { is } \\
\text { significant, an important ion exchanged is presumed }\end{array}$ & 5 & 25 & 2 & 10 \\
\hline 3 & $\begin{array}{l}\mathrm{HCO}_{3} \text { and } \mathrm{Na} \text { are dominant, normally indicates ion } \\
\text { exchanged water, although the generation of } \mathrm{CO}_{2} \text { at } \\
\text { depth can produce } \mathrm{HCO}_{3} \text { where } \mathrm{Na} \text { is dominant } \\
\text { under certain circumstances }\end{array}$ & 1 & 5 & 3 & 15 \\
\hline 4 & $\begin{array}{l}\mathrm{SO}_{4} \text { dominant, or anion discriminant and Ca dominant; } \\
\text { mixed water or water exhibiting simple dissolution may } \\
\text { be indicated. }\end{array}$ & 7 & 35 & 6 & 30 \\
\hline 5 & $\begin{array}{l}\text { No dominant anion or cation, indicates water } \\
\text { exhibiting simple dissolution or mixing }\end{array}$ & 4 & 20 & 1 & 5 \\
\hline 6 & $\begin{array}{l}\mathrm{SO}_{4} \text { dominant or anion discriminate and } \mathrm{Na} \text { dominant; } \\
\text { is water type that is not frequently encountered and } \\
\text { indicates probable mixing or uncommon } \\
\text { dissolution influences. }\end{array}$ & 2 & 10 & 7 & 35 \\
\hline
\end{tabular}




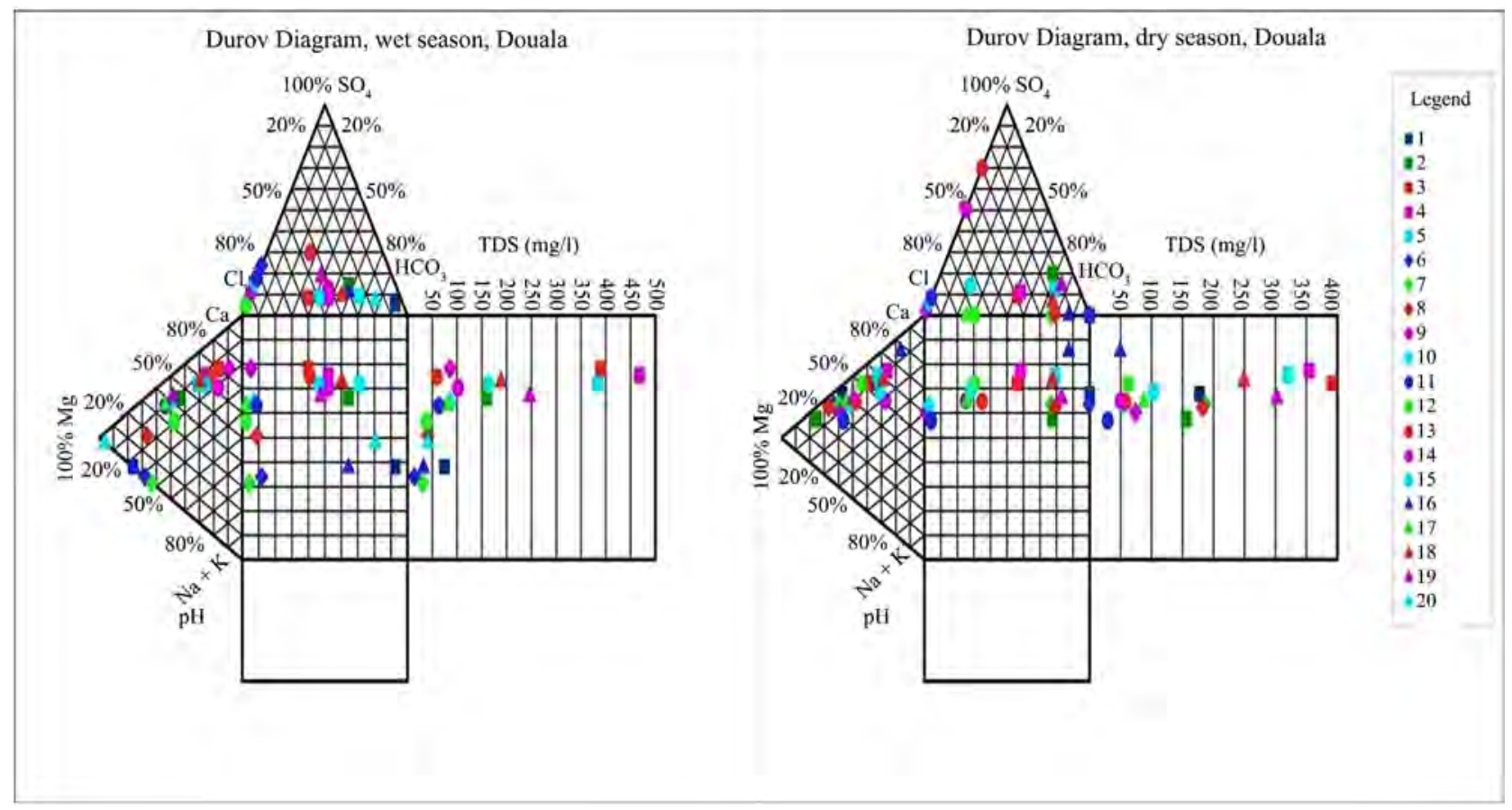

Figure 11. Durov diagrams of Douala groundwater: Six classes of processes occur in the wet and dry seasons each.

\subsection{Water Quality}

\subsubsection{Domestic Water Quality}

Ionic content of water in the study area was used to evaluate groundwater suitability for domestic use: The recommended values are of the [26] guidelines. The quality guidelines for drinking water have been specified by [26]. The suitability of groundwater in the study area based on the water quality index WQI and total hardness $\mathrm{H}_{\mathrm{T}}$ have the values presented in Table 8 .

\subsubsection{Water Quality Index (WQI)}

The guidelines for permissible concentrations of ions in groundwater [26] were used to calculate WQI values [27]. Water Quality Index WQI is considered the most effective tool to convey the water quality information in its simplest form to the public [28]. WQI values in Douala City ranged from -2.8 10.9 in the wet season and $8.8-81.5$ in the dry season. Groundwater in Douala is excellent to very poor for domestic use as shown in Figure 12 and presented in Table 8.

\subsubsection{Total Hardness}

The total hardness of groundwater samples range from $5.13-294.62 \mathrm{mg} / \mathrm{L}$ in the wet season and $42.63-402.3 \mathrm{mg} / \mathrm{L}$ in the dry season as seen in Figure 13.60\% of groundwater in the study area can be classified as soft, $20 \%$ fell in the moderately hard category, and $20 \%$ in the wet season is hard water that may be a potential health risk factor whereas in the dry season $15 \%$ of groundwater in the study area can be classified as soft, $55 \%$ fell into the moderately hard category, $15 \%$ is hard water and $15 \%$ is very hard [29] as presented in Table 8. 


\subsection{Water Quality for Irrigational Use}

The important parameters which determine the irrigation water quality of the study area.

Table 8. Water quality classifications: WQI, Hardness, SAR, USSL, PI, MAR, RSC and KR indices, Douala.

\begin{tabular}{|c|c|c|c|c|c|c|}
\hline \multicolumn{7}{|c|}{ Water quality classifications: WQI, Hardness, SAR, USSL, PI, MAR, RSC and KR indices, Douala } \\
\hline \multirow{2}{*}{ Class } & \multirow{2}{*}{ Values } & \multirow{2}{*}{ Quality } & \multicolumn{2}{|c|}{ Wet } & \multicolumn{2}{|c|}{ Dry } \\
\hline & & & No & $\%$ & No & $\%$ \\
\hline \multicolumn{7}{|c|}{ WQI Classification } \\
\hline 1 & $0-25$ & Excellent & 20 & 100 & 12 & 60 \\
\hline 2 & $26-50$ & Good & 0 & 0 & 4 & 20 \\
\hline 3 & $51-75$ & Poor & 0 & 0 & 3 & 15 \\
\hline 4 & $76-100$ & Very poor & 0 & 0 & 1 & 5 \\
\hline \multicolumn{7}{|c|}{ Hardness Classification } \\
\hline 1 & $0-75$ & Soft & 12 & 60 & 3 & 15 \\
\hline 2 & $76-150$ & Moderately Hard & 4 & 20 & 11 & 55 \\
\hline 3 & $151-300$ & Hard & 4 & 20 & 3 & 15 \\
\hline 4 & $>300$ & Very Hard & 0 & 0 & 3 & 15 \\
\hline \multicolumn{7}{|c|}{ SAR Classification } \\
\hline $\mathrm{S}_{1}$ & $<10$ & Excellent & 20 & 100 & 20 & 100 \\
\hline \multicolumn{7}{|c|}{ USSL Classification } \\
\hline $\mathrm{C}_{1}$ & $101-250$ & Very Good & 3 & 15 & 9 & 45 \\
\hline $\mathrm{C}_{2}$ & $251-750$ & Good & 16 & 80 & 10 & 50 \\
\hline $\mathrm{C}_{3}$ & $751-2250$ & Doubtful & 1 & 5 & 1 & 5 \\
\hline \multicolumn{7}{|c|}{ PI Classification } \\
\hline Class I & $>75$ & Excellent & 2 & 10 & 4 & 20 \\
\hline Class II & $50-75$ & Good & 13 & 65 & 16 & 80 \\
\hline Class III & 25 & Unsuitable & 5 & 25 & - & - \\
\hline \multicolumn{7}{|c|}{ MAR Classification } \\
\hline 1 & $<50$ & Suitable & 9 & 45 & 8 & 40 \\
\hline 2 & $>50$ & Unsuitable & 11 & 55 & 12 & 60 \\
\hline \multicolumn{7}{|c|}{ RSC Classification } \\
\hline 1 & $<1.25$ & Good & 20 & 100 & 20 & 100 \\
\hline \multicolumn{7}{|c|}{ KR Classification } \\
\hline 1 & $<1$ & Suitable & 20 & 100 & 20 & 100 \\
\hline
\end{tabular}




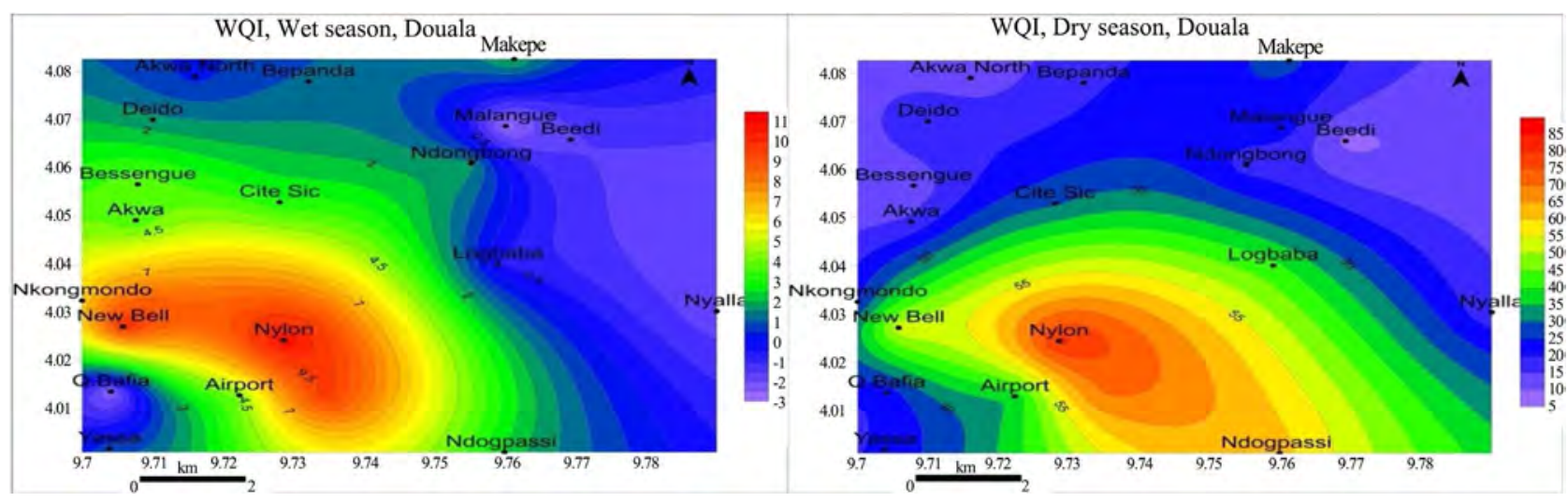

Figure 12. Spatial variation of water quality index during wet and dry seasons; note increase in WQI values during the dry season and decrease WQI values in the wet season.

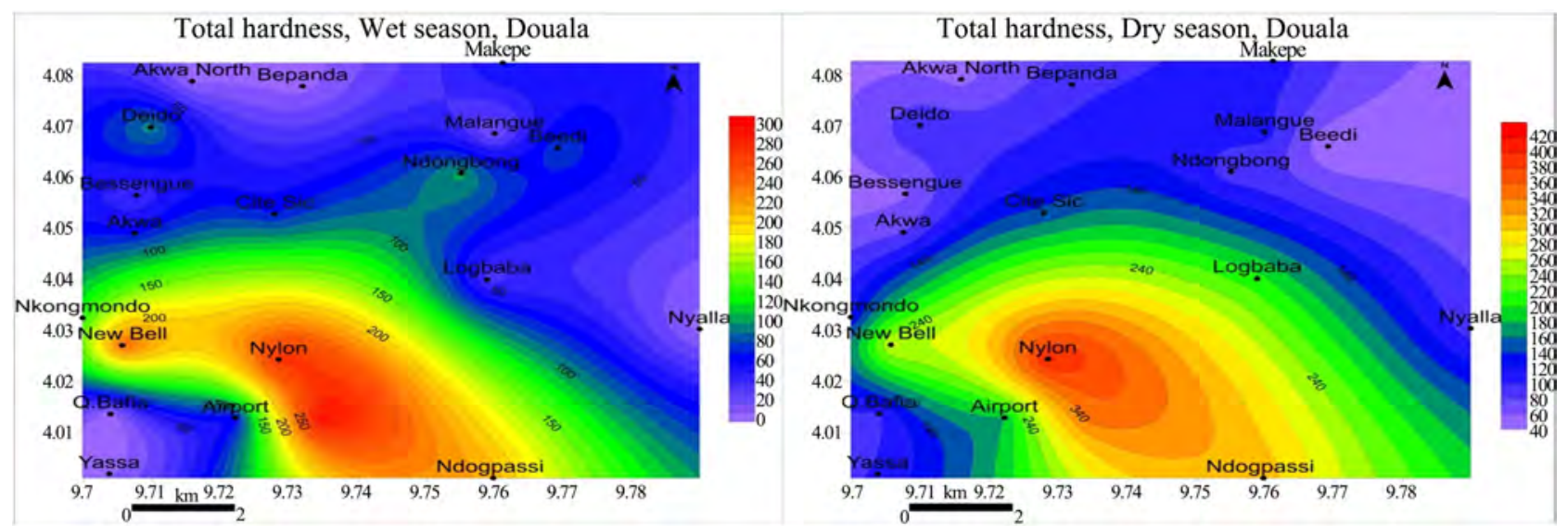

Figure 13. Spatial variation of total hardness in study area during wet and dry season; $60 \%$ of groundwater in the study area can be classified as soft.

\subsubsection{Sodium Percent}

Sodium along with carbonate forms alkaline soil; while sodium with chloride forms saline soil; both of these are not suitable for the growth of plants [30]. The quality classifications of irrigation water based on the values of sodium percentage [15] suggest that the groundwater of the study area is excellent-to-good and good-to-permissible category for both seasons as shown in Figure 14, indicating the water is suitable for irrigation.

\subsubsection{Sodium Adsorption Ratio}

The USSL Salinity Hazard Classification to crop irrigation is measured by the specific conductance [31]. SAR values ranged from $0.01-0.05$ in rainy season and $0.0-0.06$ during the dry season as seen in Figure 15. All the 20 groundwater samples fell in the $\mathrm{S}_{1}$ class Table 8 for both rainy season and dry season considered suitable for irrigation. In the Wet season 3 samples $15 \%$ plotted in the very good field, 16 samples $30 \%$ potted in the good field and 1 sample $5 \%$ plotted in the doubtful field whereas during the dry season 9 samples $45 \%$ plotted in the very good field, 10 samples $50 \%$ plotted in the good field and 1 sample $5 \%$ plotted in the doubtful field as shown in Figure 16 and presented in Table 8. 


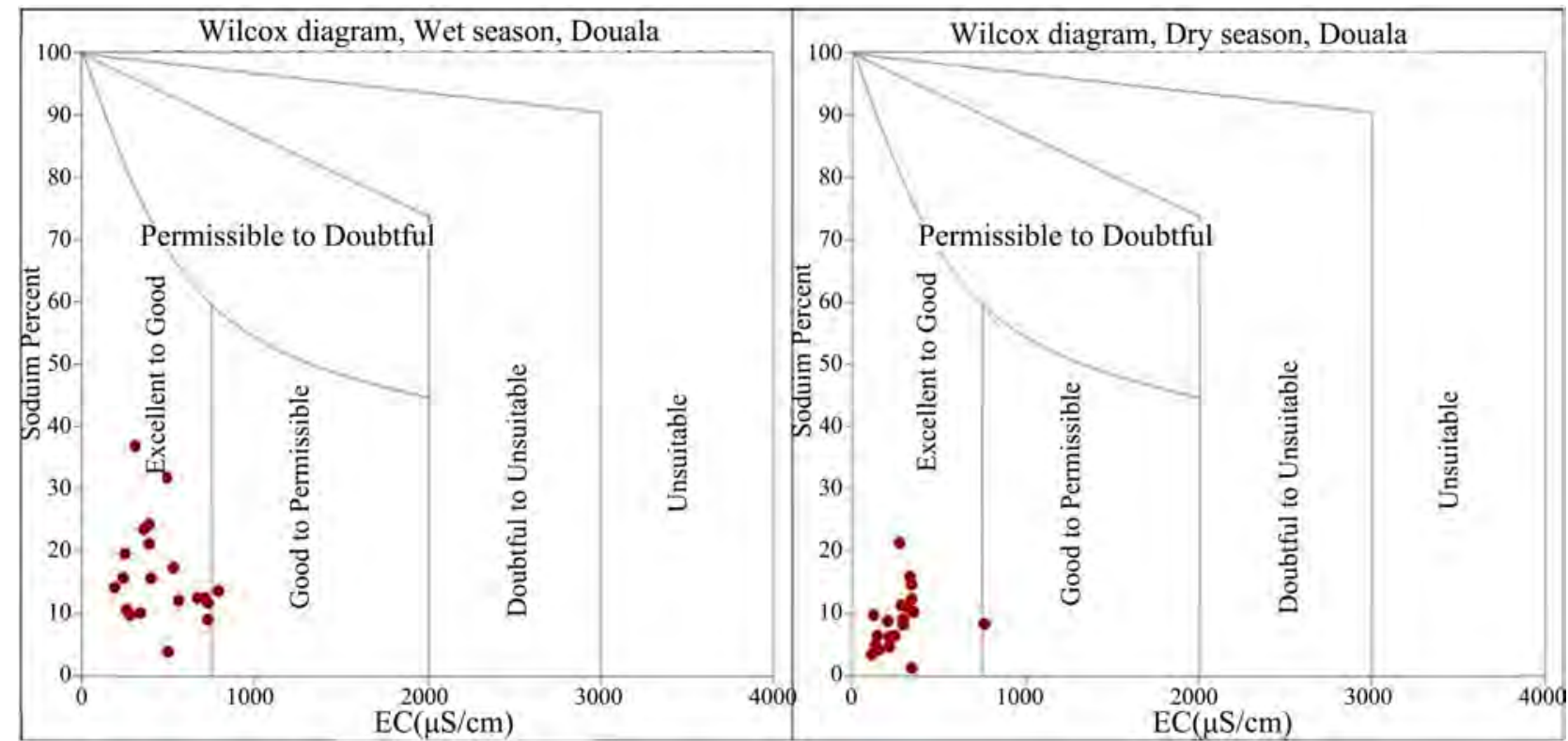

Figure 14. Wilcox diagram showing groundwater suitability for irrigation with all the water samples plotting in excellent to good and good to permissible fields in both wet and dry seasons indicating that the water is suitable for irrigation.

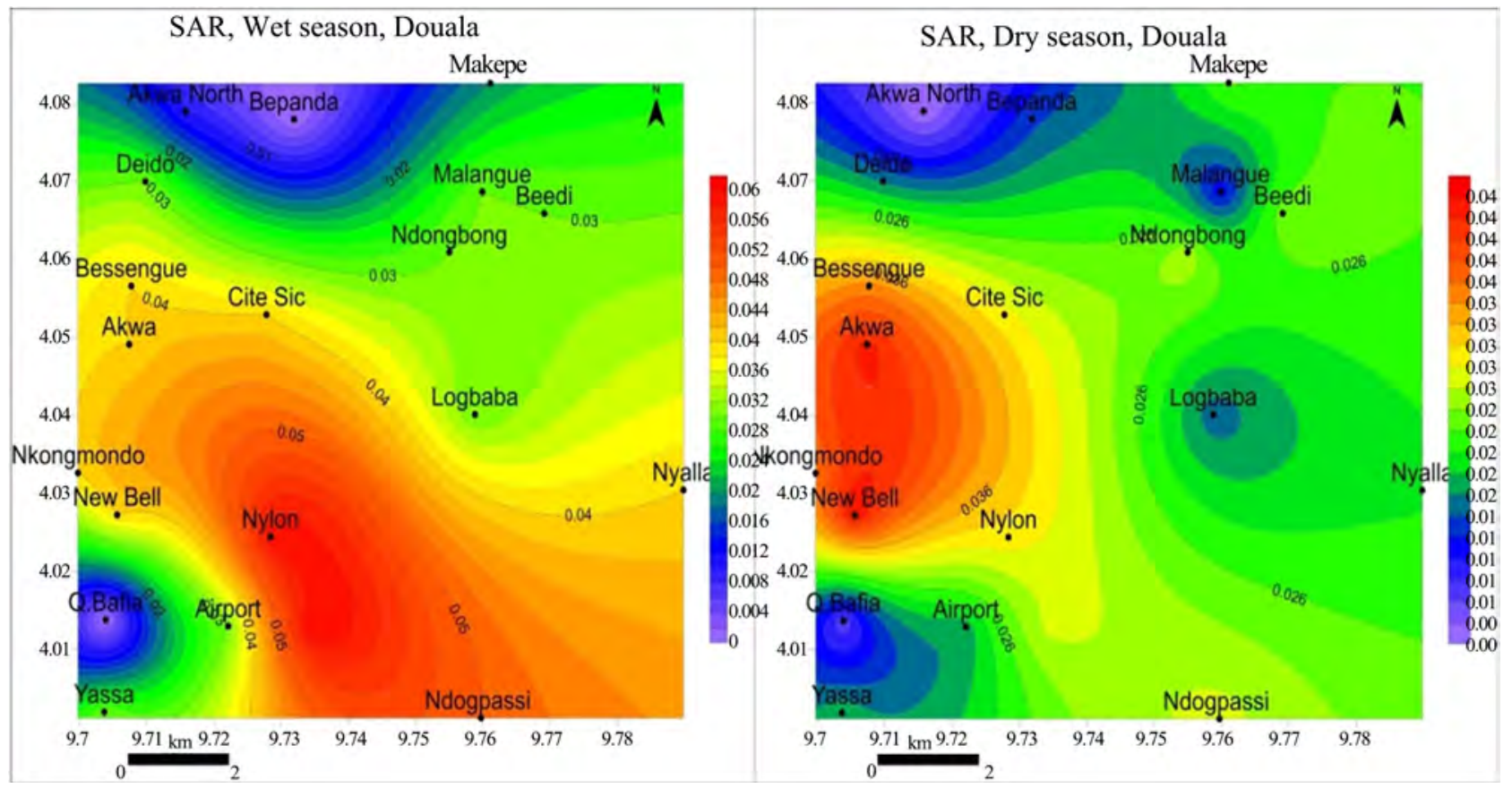

Figure 15. Spatial variation of Sodium adsorption ratio during wet and dry season; Note increase in SAR values during the dry season while in the wet season the SAR values decrease.

\subsubsection{Permeability Index}

The classification of irrigation waters has been attempted on the basis of permeability Index [21]. The groundwater samples of the study area fell in class-I, II, and III as per Doneen chart, the groundwater samples of the study area are of good quality for irrigation except for 5 samples that plotted in the class III field in the wet season as shown in Figure 17 and presented in Table 8. 


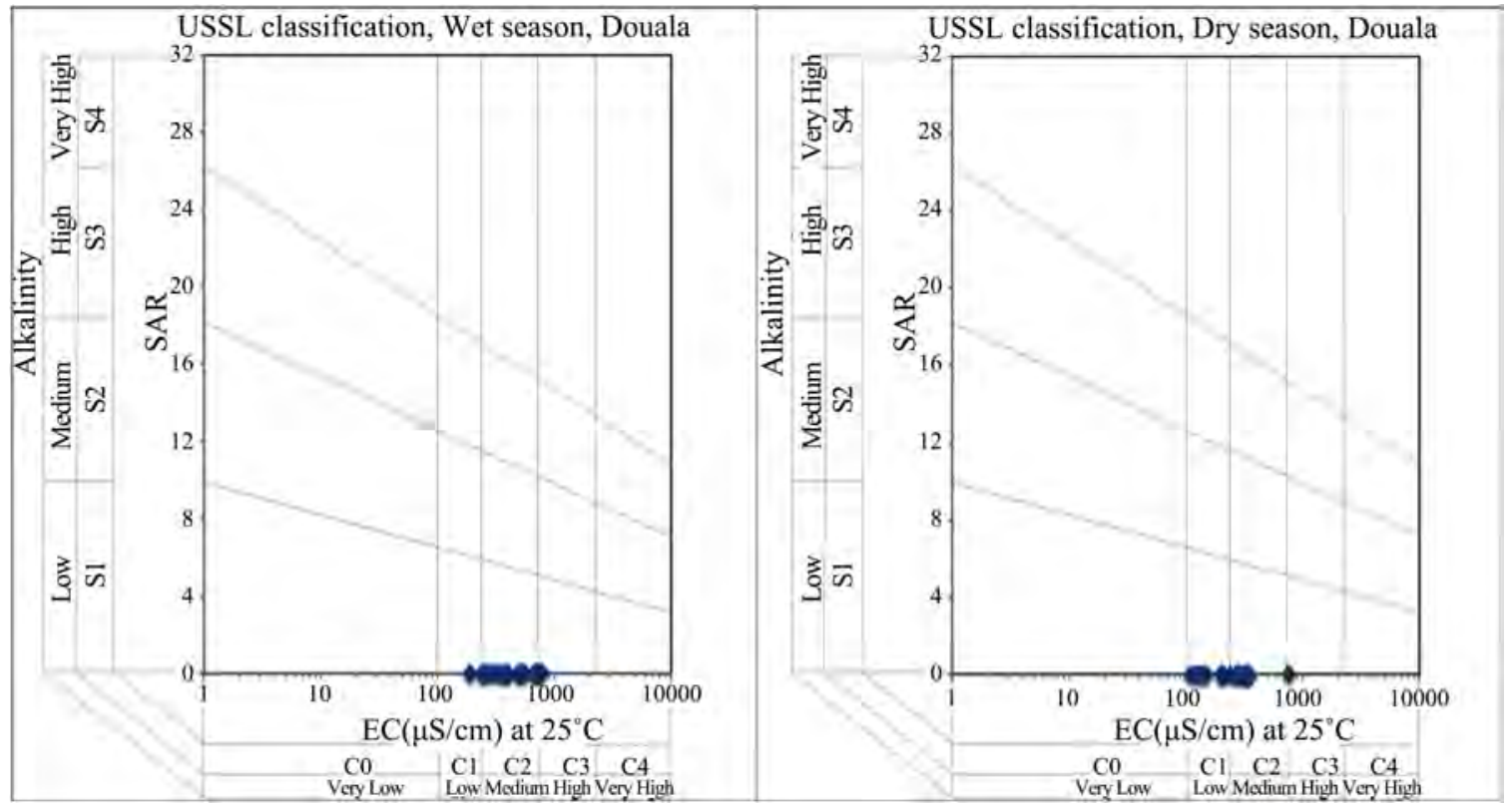

Figure 16. Residual Salinity Hazard classification, Douala; The $\mathrm{S}_{1} \mathrm{C}_{0}, \mathrm{~S}_{1} \mathrm{C}_{1}$, and $\mathrm{S}_{1} \mathrm{C}_{2}$ make up the excellent, very good and good fields respectively. In the Wet season 3 samples $15 \%$ plotted in the very good field, 16 samples $30 \%$ potted in the good field and 1 sample 5\% plotted in the doubtful field whereas during the dry season 9 samples $45 \%$ plotted in the very good field, 10 samples $50 \%$ plotted in the good field and 1 sample $5 \%$ plotted in the doubtful field.

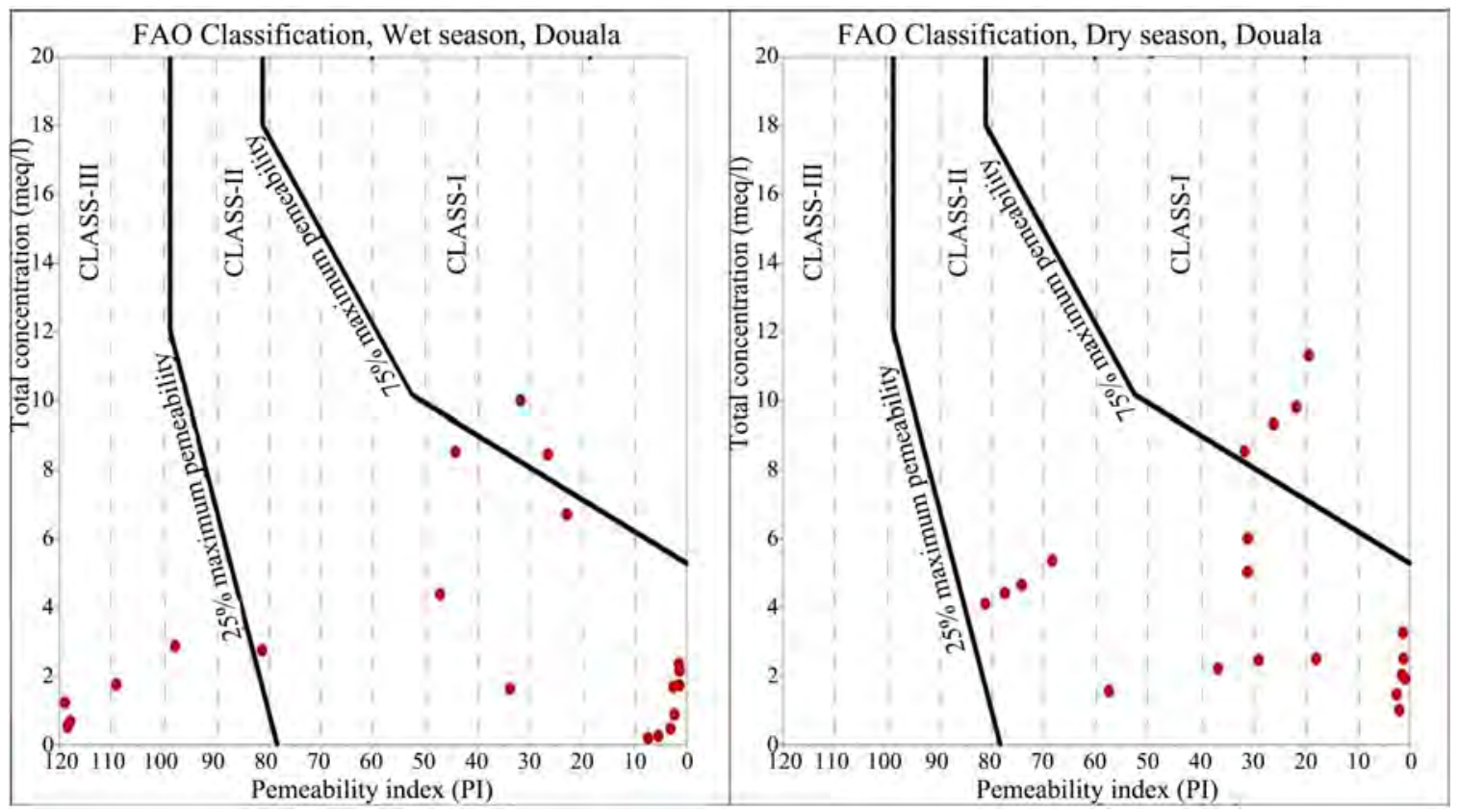

Figure 17. FAO classification of groundwater for irrigation indicating that the water is suitable for irrigation in the dry season. It is that the samples plot in class I and class II field with 5 samples plotting in the class III field during the wet season.

\subsubsection{Magnesium Adsorption Ratio}

Magnesium adsorption ratio values ranged from $11-100$ in the wet season and $17.87-79.32$ in the dry season as in Figure 18. Magnesium adsorption ratio less than $50 \%$ it is considered suitable for irrigation purpose. In the study area, $45 \%$ of the samples are suitable for irrigation during the wet season whereas $40 \%$ of 
the samples are suitable for irrigation during the dry season; $55 \%$ of the samples are unsuitable for irrigation during the wet season whereas $60 \%$ of the samples are unsuitable for irrigation during the dry season presented in Table 8.

\subsubsection{Residual Sodium Carbonate}

The RSC values ranged from $-3.79-1$ in the wet season and $-5.38-0.38$ in the dry season as in Figure 19. All the RSC values are $<1.25$ in the study area thus rendering the water suitable for irrigation in both seasons presented in Table 8 .

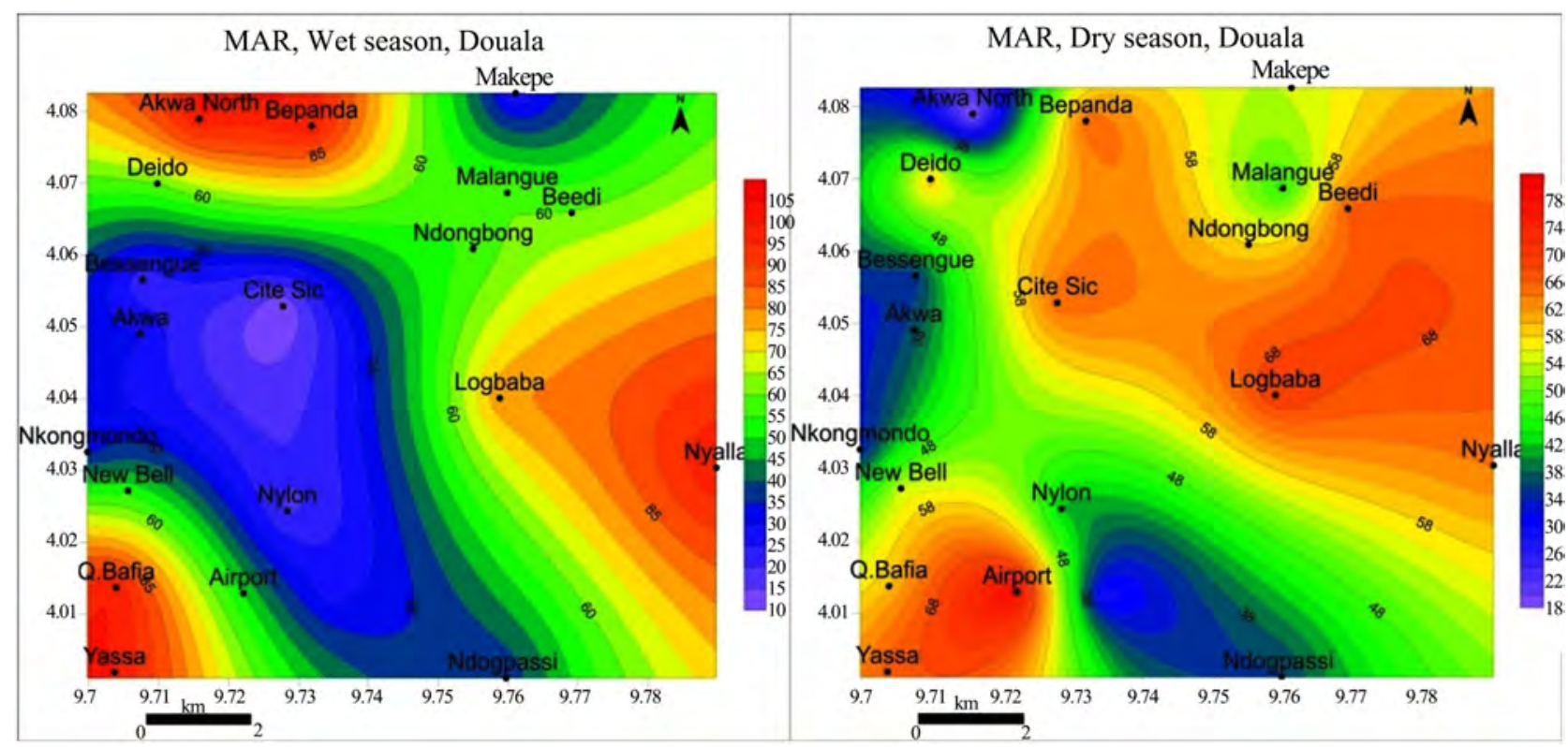

Figure 18. Spatial variation of Magnesium adsorption ratio in the study area during wet season and dry season; note increase in MAR values during the wet season while in the dry seasons the MAR values decrease at Akwa, Nkongmondo, and Ndogpassi.

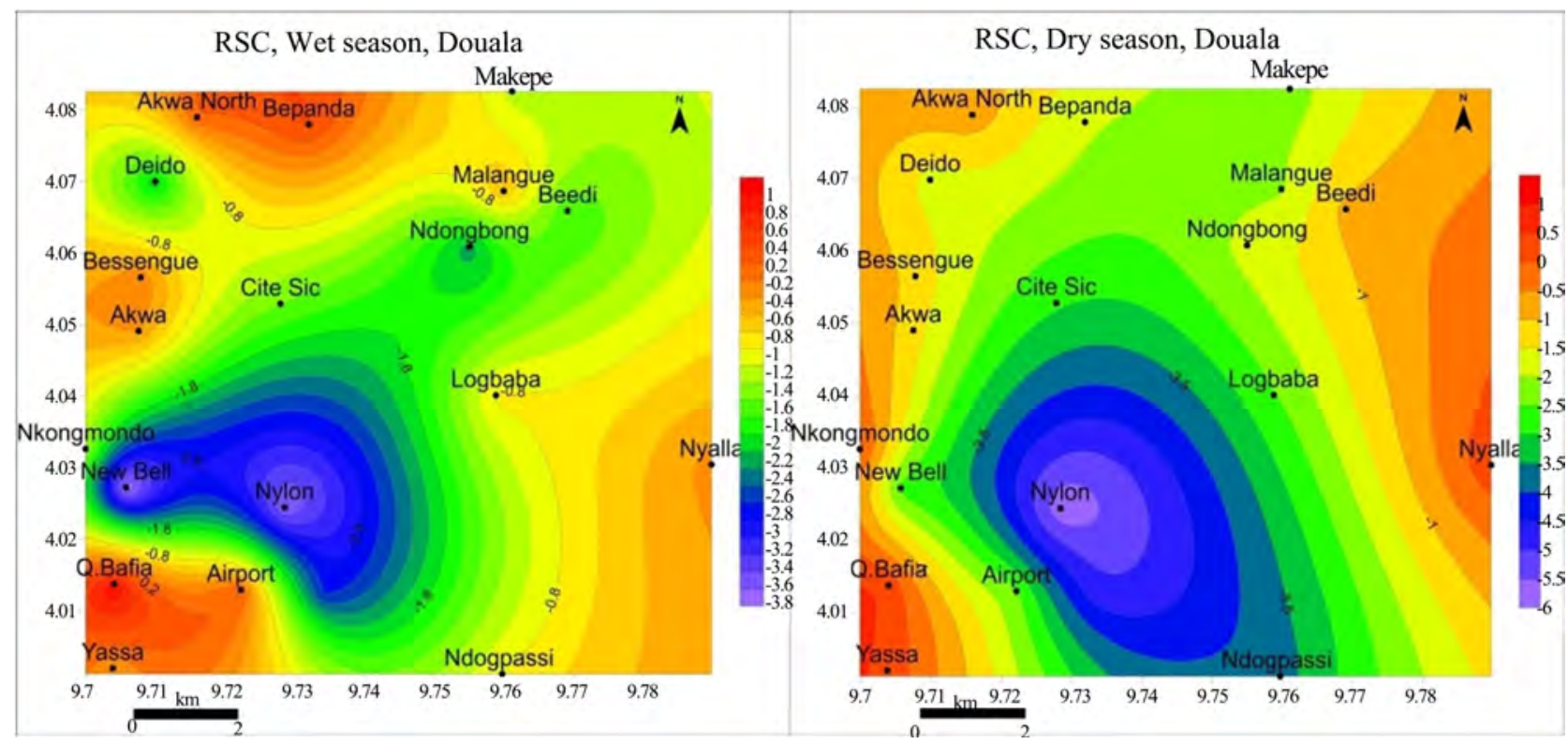

Figure 19. Spatial variation of Residual sodium carbonate in the study area during wet and dry season; note decrease in RSC values during the dry season while in the wet season the RSC values increases. 


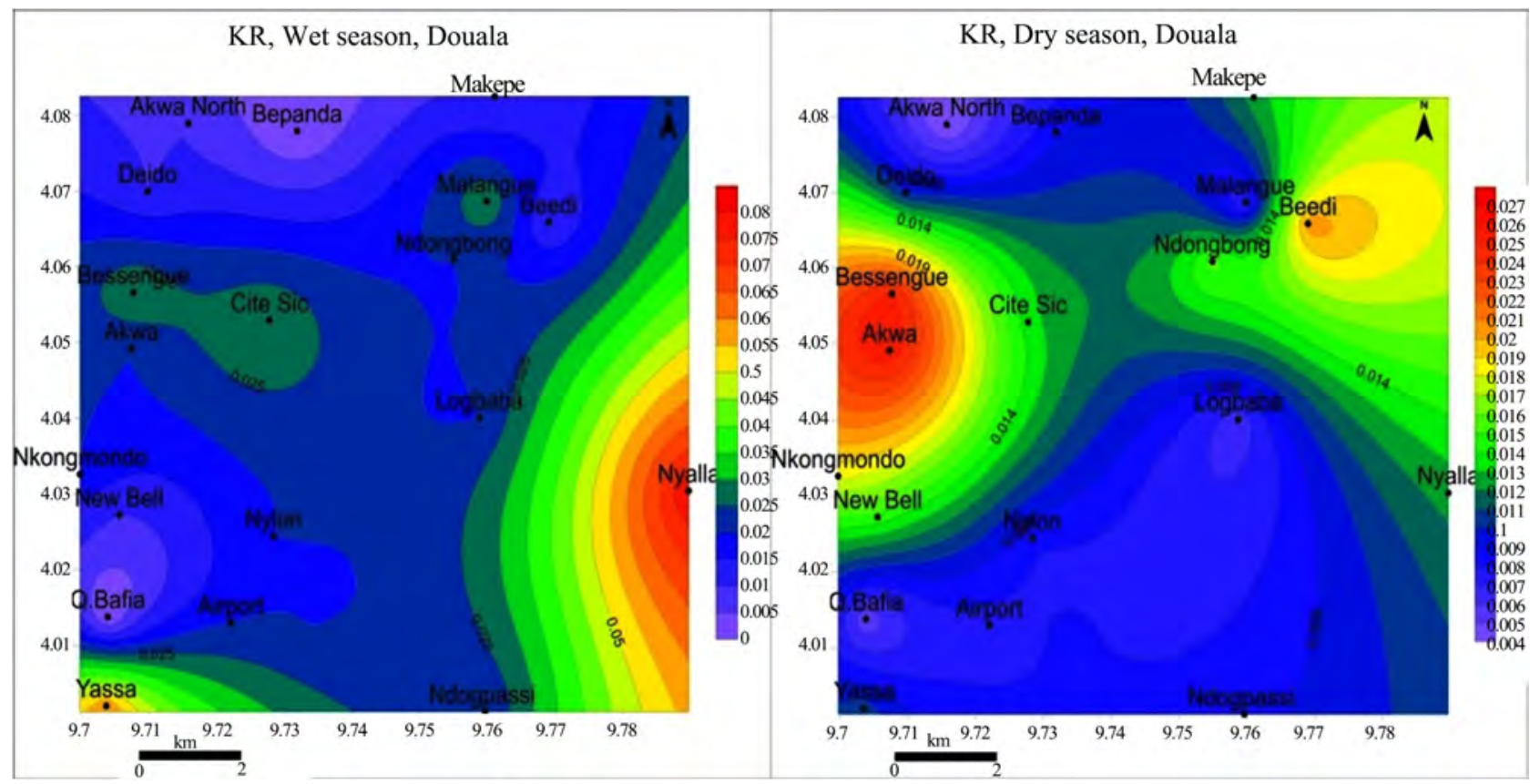

Figure 20. Spatial variation of Kelly's ratio during wet and dry season; note decrease in KR value during the dry season and increases in the wet season.

\subsubsection{Kelly's Ratio}

$\mathrm{KR}<1$ is considered suitable for irrigation and KR $>1$ is unsuitable. During rainy season, $\mathrm{KR}$ values vary between $0.00-0.08$ during the wet season and during the dry season the values vary between $0.00-0.03$ as in Figure 20. All groundwater samples in Douala are suitable for irrigation for both seasons presented in Table 8.

\section{Discussion}

There is a seasonal variation of temperature, $\mathrm{pH}, \mathrm{EC}$, and TDS as such the groundwater is in hydraulic connectivity with the atmosphere indicative of a phreatic aquifer. All the major ions fell below acceptable limits for both seasons [26]. From the ionic ratios there are additional sources of $\mathrm{SO}_{4}$ and silicate weathering possibly of the rocks in this area; weathering of Na-feldspar, other Na-silicates and Ca-carbonate dissolution or Ca-silicate weathering. Cation-exchange of the silicate rocks with the groundwater. Ironic ratio values for nitrate and sulfate are very low as such there are no anthropogenic contribution and no oxidation of sulphides. Solutes from weathering reactions and inputs of dissolved species in precipitation get into the aquifer indicating a recharge zone. From Gibbs diagram there is the dominance of rock-weathering indicating that rock weathering is the mechanism controlling groundwater chemistry in the area. From Durov diagrams the processes involved are; ion exchange, dissolution and simple mixing of groundwater. From Piper's diagrams, the dominant resultant hydrogeochemical facies are $\mathrm{Ca}-\mathrm{Mg}-\mathrm{Cl}-\mathrm{SO}_{4}$ and $\mathrm{Ca}-\mathrm{Mg}-\mathrm{HCO}_{3}$ for both seasons. These facies are characteristic of freshly recharged groundwater that has 
equilibrated with $\mathrm{CO}_{2}$ and soluble carbonate minerals under open system conditions in the vadose zone typical of shallow groundwater flow systems in phreatic aquifers.

\section{Conclusions}

From the above data synthesis, all physicochemical parameters vary with season indicating seasonal influence on all the phreatic aquiferous formations:

The $\mathrm{pH}$ indicates that groundwater is acidic to alkaline in all seasons.

All ionic concentrations fall below acceptable WHO limits in all seasons.

Groundwater in Douala is made up of two water types: $\mathrm{CaHCO}_{3}$ and $\mathrm{MgCl}$.

There are two hydrogeochemical facies: $\mathrm{Ca}-\mathrm{Mg}-\mathrm{Cl}-\mathrm{SO}_{4}$ hydrogeochemical facies characteristic of groundwater some distance along its flow path and $\mathrm{Ca}-\mathrm{Mg}-\mathrm{HCO}_{3}$ hydrogeochemical facies characteristic of freshly recharged groundwater that has equilibrated with $\mathrm{CO}_{2}$ and soluble carbonate minerals under open system conditions in the vadose zone typical of shallow groundwater flow systems in phreatic aquifers.

The Water Quality Index (WQI) for groundwater in Douala is excellent to very poor for domestic use.

The groundwater indices of Sodium Percent (\% Na), Residual Sodium Carbonate (RSC), Kelley's ratio (KR), Sodium Adsorption Ratio (SAR), Electrical Conductivity (EC), Total Dissolved Solids (TDS), USSL and Wilcox index were determined, evaluated and found to be suitable for agro-industrial uses in all seasons.

Permeability Index (PI) and Magnesium Adsorption Ratio (MAR) were not suitable in some areas and in some seasons.

\section{Conflicts of Interest}

The authors declare no conflicts of interest regarding the publication of this paper.

\section{References}

[1] Guévart, E., Noeske, J., Solle, J., Essomba, J.M., Edjenguele, M., Bita, A., Mouangue, A. and Manga, B. (2006) Déterminats du cholera á Douala. Medecin Tropical, 66, 283-291.

[2] Asaah, V.A., Abimbola, A.F. and Suh, C.E. (2006) Heavy Metal Concentration and Distribution in Surface Soils of the Bassa Industrial Zone 1, Douala, Cameroon. The Arab. The Arabian Journal for Science and Engineering, 31, 147-158.

[3] Akenji, V.N., Ako, A.A., Akoachere, R.A. and Hosono, T. (2015) DRASTIC-GIS Model for Assessing Vulnerability to Pollution of the Phreatic Aquiferous Formations in Douala-Cameroon. Journal of African Earth Science, 102, 180-190.

[4] Ndjama, J., Kamgang, K., Sigha, N., Ekodeck, G. and Tita, M. (2008) Water Supply, Sanitation and Health Risks in Douala, Cameroon. African Journal of Environmental Science and Technology, 2, 422-429.

[5] Ketchemen, B.T. (2011) Déterminantshydrogéologiques de la complexité du 
systèmeaquifère du basin sédimentaire de douala (Cameroun). $\mathrm{PhD}$. Thesis, University of Cheikh Anta Diop, Dakar, Senegal.

[6] Eneke, G.T., Ayonghe, S.N., Chandrasekharam, D., Ntchancho, R., Ako, A.A., Mouncherou, O. and Thambidurai, P. (2011) Controls on Groundwater Chemistry in a Highly Urbanised Coastal Area. International Journal of Environmental Research, 5, 475-490.

[7] Kenfack, P.L., Njike, P.R.N., Ekodeck, G.E. and Ngueutchoua, G. (2012) Fossils Dinoflagellates from the Northern Border of the Douala Sedimentary Sub-Basin (South-West Cameroon): Age Assessment and Paleoecological Interpretations. Geosciences, 2, 117-124.

[8] ISO (2006) Standard ISO 5667 1: Water Quality-Sampling-Part 1: Guidance on the Design of Sampling Programs and Sampling Techniques. International Organization for Standardization, Geneva.

[9] ISO (2003) Standard ISO 5667 3: Water Quality-Sampling-Part 3: Guidance on the Preservation and Handling of Water Samples. International Organization for Standardization, Geneva.

[10] ISO (2009) Standard ISO 5667-11: Water Quality-Sampling-Part 11: Guidance on Sampling of Groundwaters. International Organization for Standardization, Geneva.

[11] American Public Health Association, APHA (1995) Standard Methods for Examination of Water and Waste Water. American Water Works Association and Water Pollution Control Federation, Washington DC, USA.

[12] Hounslow, A.W. (1995) Water Quality Data: Analysis and Interpretation. Lewis Publishers CRC Press, New York, 397.

[13] Langguth, H.R. (1966) Groundwater verhaltisse in Bereiech Des Velberter Sattles. Der Minister Fur Eraehrung, Land Wirtsch Forste Duesseldorf: NRW, 127.

[14] Lloyd, J.A. and Heathcote, J.A. (1985) Natural Inorganic Hydrochemistry in Relation to Groundwater: An Introduction. Oxford University Press, New York, 296.

[15] Wilcox, L.V. (1995) Classification and Use of Irrigation Waters. U.S.D.A Circular No. 960, Washington DC, 19.

[16] Kelley, W.P. (1940) Permissible Composition and Concentration of Irrigation Waters, Proceedings of the American Society of Civil Engineers, 66, 607-613.

[17] Paliwal, K.V. (1972) Irrigation with Saline Water. Monogram No. 2 (New Series), IARI, New Delhi, 198.

[18] Todd, D.K. (1980) Ground Water Hydrogeology. Wiley International Edition, John Wiley \& Sons Inc., New York.

[19] Eaton, E.M. (1950) Significance of Carbonate in Irrigation Water. Soil Science, 69, 123-133. https://doi.org/10.1097/00010694-195002000-00004

[20] Richards, L.A. (1954) Diagnosis and Improvement of Saline Alkali Soils: Agriculture. Vol. 160, Handbook 60, USDA, Washington DC.

[21] Doneen, L.D. (1962) The Influence of Crop and Soil on Percolating Water. Proceeding of Biennial Conference on Groundwater Recharge 1961, California, USA, 156-163.

[22] Sisodia, R. and Moundiotiya, C. (2006) Assessment of the Water Quality Index of Wetland Kalakho Lake, Rajasthan, India. Journal of Environmental Hydrology, 14, $1-11$.

[23] Gibbs, R.J. (1970) Mechanisms Controlling World's Water Chemistry. Science, 170, 1088-1090. https://doi.org/10.1126/science.170.3962.1088 
[24] Piper, A.M. (1944) A Graphic Procedure in the Geochemical Interpretation of Water Analysis. American Geophysical Union Transactions, 25, 914-928. https://doi.org/10.1029/TR025i006p00914

[25] Durov, S.A. (1948) Classification of Natural Waters and Graphical Representation of Their Composition. Doklady Akademii Nauk SSSR, 59, 87-90.

[26] World Health Organization (2017) Guidelines for Drinking-Water Quality. 4th Edition, Incorporating the First Addendum, Geneva.

[27] Asadi, J.J., Vuppala, P., Reddy, M.A. (2007) Remote Sensing and GIS Techniques for Evaluation of Groundwater Quality in Municipal Corporation of Hyderabad (Zone-V), India. International Journal of Environmental Research and Public Health, 4, 45-52. https://doi.org/10.3390/ijerph2007010008

[28] Babaei, S.F. (2011) Evolution of a New Surface Water Quality Index for Karoon Catchment in Iran. Journal of Water Science and Technology, 64, 2483-2491. https://doi.org/10.2166/wst.2011.780

[29] Sawyer, G.N. and McCarthy, D.L. (1967) Chemistry of Sanitary Engineers. 2nd Edition, McGraw Hill, New York, 518.

[30] Pandian, K. and Sankar, K. (2007) Hydrochemistry and Groundwater Quality in the Vaippar River Basin, Tamil Nadu. Journal of the Geological Society of India, 69, 970-982.

[31] United States Salinity Laboratory (1954) Diagnosis and Improvement of Saline and Alkali Soils (Agriculture Hand Book No. 60), United States Department of Agriculture, USDA, Washington DC. 